\title{
Photolysis imprint in the nitrate stable isotope signal in snow and atmosphere of East Antarctica and implications for reactive nitrogen cycling
}

\author{
M. M. Frey ${ }^{1,2}$, J. Savarino ${ }^{1}$, S. Morin ${ }^{1, *}$, J. Erbland ${ }^{1}$, and J. M. F. Martins ${ }^{3}$ \\ ${ }^{1}$ Université Joseph Fourier - Grenoble 1/CNRS-INSU, Laboratoire de Glaciologie et Géophysique de l'Environnement, \\ St. Martin d'Hères, France \\ ${ }^{2}$ British Antarctic Survey, Natural Environment Research Council, Cambridge, UK \\ ${ }^{3}$ Université Joseph Fourier - Grenoble 1/CNRS-INSU/G-INP/IRD, Laboratoire d'étude des Transferts en Hydrologie et \\ Environnement, St. Martin d'Hères, France \\ *now at Météo-France/CNRS, CNRM-GAME, CEN, St. Martin d'Hères, France
}

Received: 3 May 2009 - Published in Atmos. Chem. Phys. Discuss.: 27 May 2009

Revised: 22 September 2009 - Accepted: 2 November 2009 - Published: 16 November 2009

\begin{abstract}
The nitrogen $\left(\delta^{15} \mathrm{~N}\right)$ and triple oxygen $\left(\delta^{17} \mathrm{O}\right.$ and $\left.\delta^{18} \mathrm{O}\right)$ isotopic composition of nitrate $\left(\mathrm{NO}_{3}^{-}\right)$was measured year-round in the atmosphere and snow pits at Dome $\mathrm{C}$, Antarctica $\left(\mathrm{DC}, 75.1^{\circ} \mathrm{S}, 123.3^{\circ} \mathrm{E}\right)$, and in surface snow on a transect between DC and the coast. Comparison to the isotopic signal in atmospheric $\mathrm{NO}_{3}^{-}$shows that snow $\mathrm{NO}_{3}^{-}$is significantly enriched in $\delta^{15} \mathrm{~N}$ by $>200 \%$ and depleted in $\delta^{18} \mathrm{O}$ by $<40 \%$. Post-depositional fractionation in $\Delta^{17} \mathrm{O}\left(\mathrm{NO}_{3}^{-}\right)$is small, potentially allowing reconstruction of past shifts in tropospheric oxidation pathways from ice cores. Assuming a Rayleigh-type process we find fractionation constants $\varepsilon$ of $-60 \pm 15 \%$ o, $8 \pm 2 \%$ and $1 \pm 1 \%$, for $\delta^{15} \mathrm{~N}, \delta^{18} \mathrm{O}$ and $\Delta{ }^{17} \mathrm{O}$, respectively. A photolysis model yields an upper limit for the photolytic fractionation constant ${ }^{15} \varepsilon$ of $\delta^{15} \mathrm{~N}$, consistent with lab and field measurements, and demonstrates a high sensitivity of ${ }^{15} \varepsilon$ to the incident actinic flux spectrum. The photolytic ${ }^{15} \varepsilon$ is process-specific and therefore applies to any snow covered location. Previously published ${ }^{15} \varepsilon$ values are not representative for conditions at the Earth surface, but apply only to the UV lamp used in the reported experiment (Blunier et al., 2005; Jacobi et al., 2006). Depletion of oxygen stable isotopes is attributed to photolysis followed by isotopic exchange with water and hydroxyl radicals. Conversely, ${ }^{15} \mathrm{~N}$ enrichment of the $\mathrm{NO}_{3}^{-}$fraction in the snow implies ${ }^{15} \mathrm{~N}$ depletion of emissions. Indeed, $\delta^{15} \mathrm{~N}$ in
\end{abstract}

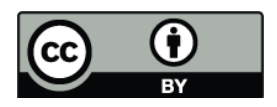

Correspondence to: M. M. Frey (maey@bas.ac.uk) atmospheric $\mathrm{NO}_{3}^{-}$shows a strong decrease from background levels $(4 \pm 7 \%$ o ) to $-35 \%$ in spring followed by recovery during summer, consistent with significant snowpack emissions of reactive nitrogen. Field and lab evidence therefore suggest that photolysis is an important process driving fractionation and associated $\mathrm{NO}_{3}^{-}$loss from snow. The $\Delta^{17} \mathrm{O}$ signature confirms previous coastal measurements that the peak of atmospheric $\mathrm{NO}_{3}^{-}$in spring is of stratospheric origin. After sunrise photolysis drives then redistribution of $\mathrm{NO}_{3}^{-}$from the snowpack photic zone to the atmosphere and a snow surface skin layer, thereby concentrating $\mathrm{NO}_{3}^{-}$at the surface. Little $\mathrm{NO}_{3}^{-}$appears to be exported off the EAIS plateau, still snow emissions from as far as $600 \mathrm{~km}$ inland can contribute to the coastal $\mathrm{NO}_{3}^{-}$budget.

\section{Introduction}

Nitrate $\left(\mathrm{NO}_{3}^{-}\right)$is the chemical species at the end of the oxidation chain of atmospheric reactive nitrogen and is one of the dominant anions present in the polar snowpack (Legrand et al., 1999). Therefore there has been vital interest in using the polar ice core record of $\mathrm{NO}_{3}^{-}$concentrations to reconstruct past levels of atmospheric nitrogen oxides $\left(\mathrm{NO}_{\mathrm{x}}=\mathrm{NO}+\mathrm{NO}_{2}\right)$ and rates of stratospheric denitrification (Mulvaney and Wolff, 1993; Wolff and Delmas, 1995). Recent studies in the Arctic and Antarctic suggested furthermore that the stable isotopic composition of $\mathrm{NO}_{3}^{-}$in snow

Published by Copernicus Publications on behalf of the European Geosciences Union. 
has great potential in providing constraints on $\mathrm{NO}_{3}^{-}$sources and $\mathrm{NO}_{\mathrm{x}}$ oxidation pathways (Hastings et al., 2004; McCabe et al., 2007; Savarino et al., 2007; Kunasek et al., 2008; Morin et al., 2008, 2009; Hastings et al., 2009).

However, post-depositional processing of $\mathrm{NO}_{3}^{-}$leads to significant mass loss and isotopic fractionation, especially at sites with low annual accumulation rates, and compromises a quantitative atmospheric interpretation of the ice core record (Mulvaney et al., 1998; Röthlisberger et al., 2002; Blunier et al., 2005; Wolff et al., 2008). Recently, the same $\mathrm{NO}_{3}^{-}$ loss from snow was related to re-emission of oxidized nitrogen species into the lower atmosphere above snow covered areas with a significant impact on tropospheric oxidant chemistry, a discovery which triggered a suite of field and lab studies (Grannas et al., 2007, and references therein). Postdepositional mass loss and isotopic fractionation at sites of intermediate annual accumulation rates may be less important (Hastings et al., 2004; Jarvis et al., 2009). However, a quantitative understanding of post-depositional processes affecting $\mathrm{NO}_{3}^{-}$concentration and isotopic composition in snow is urgently needed in order to (a) use the ice core record to reconstruct past atmospheric composition and (b) better understand current boundary layer chemistry above snow surfaces.

Both photochemical and physical processes in the upper snowpack drive the observed net loss of $\mathrm{NO}_{3}^{-}$(Röthlisberger et al., 2002), but relative contributions from UV-photolysis of $\mathrm{NO}_{3}^{-}$and evaporation of nitric acid $\left(\mathrm{HNO}_{3}\right)$ are still under debate. Model studies have shown that $\mathrm{NO}_{3}^{-}$photolysis on and in snow/ice surfaces can account for observed volumetric fluxes and concentrations of $\mathrm{NO}$ and $\mathrm{NO}_{2}$ above the Arctic and coastal Antarctic snowpack (Wolff et al., 2002; Boxe and Saiz-Lopez, 2008). But according to one model only up to $40 \%$ of $\mathrm{NO}_{3}^{-}$loss from the snow reservoir can be achieved by photolysis (Wolff et al., 2002). A recent isotopic study on Antarctic snow compared field and lab determined fractionation constants of the stable nitrogen isotope in $\mathrm{NO}_{3}^{-}$and concluded that photolysis is not the main process responsable for $\mathrm{NO}_{3}^{-}$loss at the snow surface (Blunier et al., 2005).

The following simplified reaction scheme summarizes currently known $\mathrm{NO}_{3}^{-}$photochemistry in snow:

$$
\begin{aligned}
& \mathrm{NO}_{3}^{-}+h v \rightarrow \mathrm{NO}_{2}+\mathrm{O}^{-} \\
& \mathrm{NO}_{3}^{-}+h v \rightarrow \mathrm{NO}_{2}^{-}+\mathrm{O}\left({ }^{3} \mathrm{P}\right) \\
& \mathrm{NO}_{2}^{-}+h v \rightarrow \mathrm{NO}+\mathrm{O}^{-} \\
& \mathrm{NO}_{2}^{-}+\mathrm{OH} \rightarrow \mathrm{NO}_{2}+\mathrm{OH}^{-}
\end{aligned}
$$

At surface relevant wavelengths $(>290 \mathrm{~nm}) \mathrm{NO}_{3}^{-}$photolyses in an absorption band centered around $302 \mathrm{~nm}$ (Chu and Anastasio, 2003) yielding $\mathrm{NO}_{2}$ (Reaction R1) and nitrite $\left(\mathrm{NO}_{2}^{-}\right)$(Reaction $\left.\mathrm{R} 2\right)$. $\mathrm{NO}_{2}^{-}$undergoes either photolysis with UV-absorption maxima around $318 \mathrm{~nm}$ and $354 \mathrm{~nm}$
(Reaction R3) or reacts with the hydroxyl radical $(\mathrm{OH})(\mathrm{Re}-$ action R4) to produce $\mathrm{NO}$ and $\mathrm{NO}_{2}$, respectively (Boxe and Saiz-Lopez, 2008). The oxide radical ions $\left(\mathrm{O}^{-}\right)$produced in Reactions (R1) and (R3) are immediately protonated contributing to the $\mathrm{OH}$ photo formation in snow (Anastasio et al., 2007). In addition, nitrous acid (HONO) is formed at $\mathrm{pH}<7$.

$\mathrm{NO}_{2}^{-}+\mathrm{H}^{+} \rightarrow \mathrm{HONO}$

Since Reaction (R1) exceeds Reaction (R2) by a factor 8 to 9 the dominant $\mathrm{NO}_{3}^{-}$photolysis product is $\mathrm{NO}_{2}$ followed by NO and HONO (Grannas et al., 2007).

In this study we compare for the first time measurements of the stable isotopes of oxygen and nitrogen in $\mathrm{NO}_{3}^{-}$from snow pits with year-round observations in atmospheric $\mathrm{NO}_{3}^{-}$ at Dome Concordia (from here on DC, $75.1^{\circ} \mathrm{S}, 123.3^{\circ} \mathrm{E}$, 3233 m.a.m.s.l.). Snow samples from a spatial survey on the East Antarctic ice sheet (EAIS) were also included. The purpose is (a) to evaluate post-depositional isotopic fractionation to determine the processes driving $\mathrm{NO}_{3}^{-}$loss from snow and (b) to discuss implications for reactive nitrogen cycling above Antarctica and the interpretation of the ice core record of $\mathrm{NO}_{3}^{-}$stable isotopes.

\section{Methods}

Snow pits of $6 \mathrm{~m}$ and $0.5 \mathrm{~m}$ depth were sampled at DC on 15 January 2004 and 18 December 2007 at $2-5 \mathrm{~cm}$ depth resolution. This corresponds to a sample resolution of 2-5 samples $\mathrm{yr}^{-1}$ based on published accumulation rates of 2.7-3.5 g cm${ }^{-2} \mathrm{yr}^{-1}$ (Legrand and Delmas, 1988; Röthlisberger et al., 2000) and assuming an average snow density of $0.35 \mathrm{~g} \mathrm{~cm}^{-3}$. For the purpose of investigating postdepositional isotopic fractionation we discuss only surfacenear measurements from the top $0.7 \mathrm{~m}$ and will present the interpretation of the full DC04 profile in a future manuscript (Fig. 1). Samples were collected also from the top $10 \mathrm{~cm}$ of snowpack on the logistical ground traverse returning from DC to the French coastal station Dumont d'Urville (from here on DDU, $66.7^{\circ} \mathrm{S}, 140.0^{\circ} \mathrm{E}, 40$ m.a.m.s.l.), in January 2004 (Fig. 2). Surface snow samples represent between 1 (coast) and 13 (plateau) months of past net accumulation due to the strong spatial gradient in precipitation (Pettre et al., 1986). In 2004 sample size was $3 \mathrm{~kg}$ snow to collect sufficient $\mathrm{NO}_{3}^{-}$for the replicate analysis necessary during the development of the analytical method. The optimized analysis allowed then in 2007 to decrease sample size to $0.3 \mathrm{~kg}$. In order to obtain $100 \mathrm{nmol}$ of $\mathrm{NO}_{3}^{-}$for isotopic analysis snow samples were melted and preconcentrated after Silva et al. (2000). This involved quantitative trapping of $\mathrm{NO}_{3}^{-}$on $0.2 \mathrm{ml}$ of anion exchange resin (BioRad AG 1-X8) with an exchange capacity of $1.2 \mathrm{meq} \mathrm{ml}^{-1}$, followed by elution with $5 \times 2 \mathrm{ml}$ of $\mathrm{NaCl}$ solution $(1 \mathrm{M})$ yielding $100 \%$ mass recovery within the analytical uncertainty. The 2004 snow 


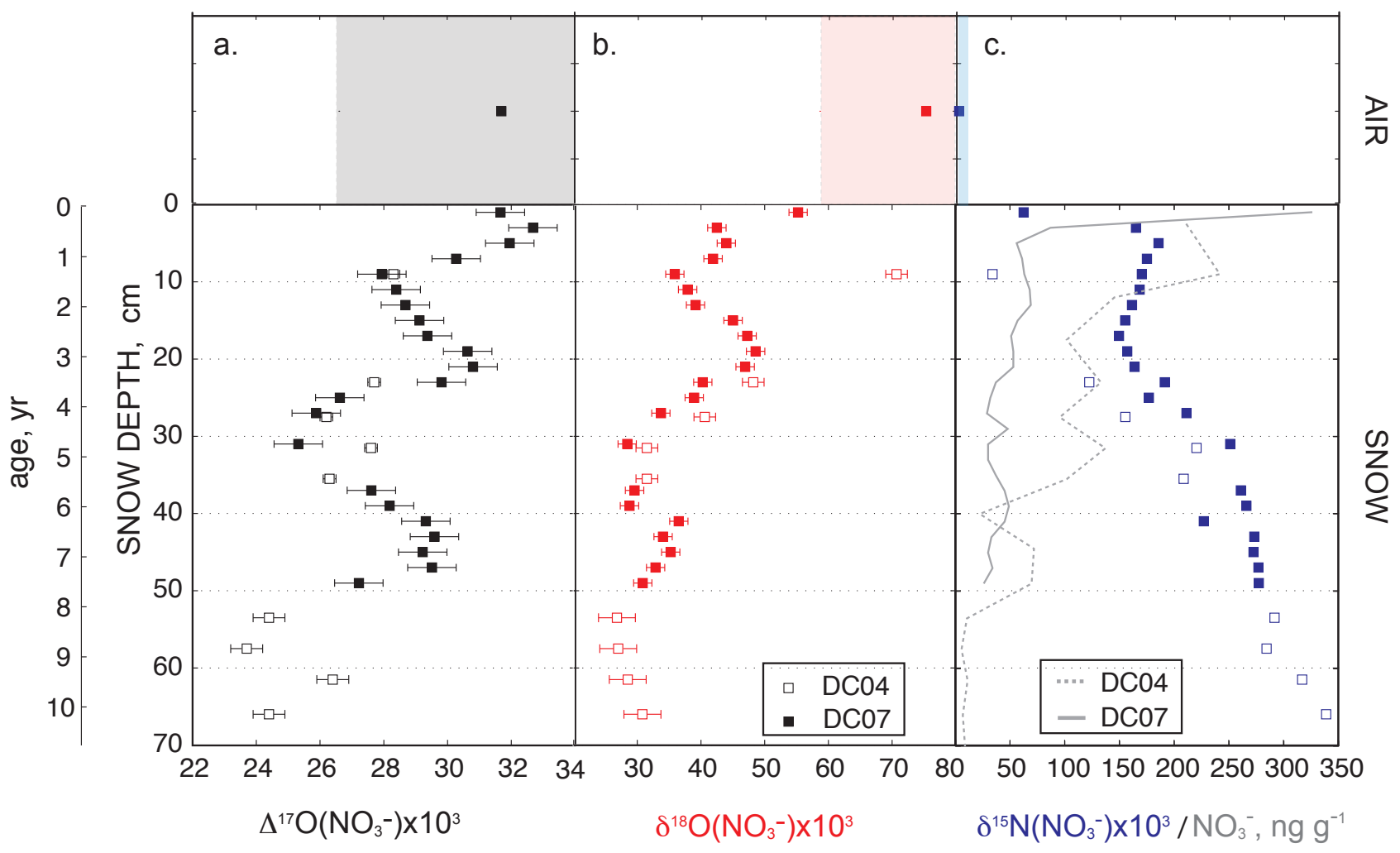

Fig. 1. $\Delta^{17} \mathrm{O}, \delta^{18} \mathrm{O}$ and $\delta^{15} \mathrm{~N}$ of $\mathrm{NO}_{3}^{-}$at Dome Concordia, East Antarctica. Top panels (a)-(c): mass-weighted averages $\pm 1 \sigma$ (symbols and shaded area) in the annual cycle of atmospheric $\mathrm{NO}_{3}^{-}$in 2007. Bottom panels (a)-(c): $\mathrm{NO}_{3}^{-}$in snow from pits collected in 2004 and 2007 with errorbars indicating the analytical error. $\mathrm{NO}_{3}^{-}$snow concentrations are shown in bottom panel of $\mathrm{c}$ (dashed and solid lines). The depth-age scale is based on measured densities and a mean annual accumulation rate of $2.7 \mathrm{~g} \mathrm{~cm}^{-2} \mathrm{yr}^{-1}$ (Röthlisberger et al., 2000).

samples were shipped frozen in double-sealed plastic bags to a commercial freezer storage facility in France, whereas 2007 samples were preconcentrated in the warm lab at DC before shipping of refrozen aliquots. $\mathrm{NO}_{3}^{-}$concentrations were determined with a colorimetric method employed on a routine basis in continuous flow analysis of polar ice cores with a detection limit of $0.5 \mathrm{ng} \mathrm{g}^{-1}$ and precision of $<3 \%$ (e.g. Frey et al., 2006).

Atmospheric $\mathrm{NO}_{3}^{-}$was collected at DC between January 2007 and January 2008 at 2-weekly resolution using a highvolume air sampler at $1.0 \mathrm{STP}-\mathrm{m}^{3} \mathrm{~min}^{-1}$. The experimental procedure was similar to that employed during previous sampling at DDU with the exception that an impactor was used at the coastal site (Savarino et al., 2007). The atmospheric $\mathrm{NO}_{3}^{-}$collected on glass fiber filters represents the sum of atmospheric particulate $\mathrm{NO}_{3}^{-}\left(p-\mathrm{NO}_{3}^{-}\right)$and gaseous nitric acid $\left(\mathrm{HNO}_{3}\right)$. The bulk of $\mathrm{HNO}_{3}$ present in the gas phase adsorbed most likely to aerosols on the filter. This is supported by the observation that second-stage filters (Whatman 41), known to trap $\mathrm{HNO}_{3}$ quantitatively (Morin et al., 2007), showed either very low $\mathrm{NO}_{3}^{-}$concentrations or none at all. After sample collection filters were stored frozen in clean $50 \mathrm{ml}$-centrifuge tubes, before shipment to France. In our laboratory the collected $\mathrm{NO}_{3}^{-}$was transferred quantitatively into solution by centrifuging the filters in $40 \mathrm{ml}$ of ultra-pure water.

We used the denitrifier method developed by Sigman et al. (2001) and Casciotti et al. (2002) and further improved by Kaiser et al. (2007) to determine the nitrogen and triple oxygen isotopic composition of $\mathrm{NO}_{3}^{-}$(further details in Morin et al., 2008, 2009). In brief, sample $\mathrm{NO}_{3}^{-}$ was quantitatively reduced into nitrous oxide $\left(\mathrm{N}_{2} \mathrm{O}\right)$ during over-night incubation in concentrated solutions of Pseudomonas aureofaciens. We employed an on-line method, where the $\mathrm{N}_{2} \mathrm{O}$ purged from the sample vials was decomposed on a gold furnace at $900^{\circ} \mathrm{C}$ into $\mathrm{O}_{2}$ and $\mathrm{N}_{2}$ followed by gas chromatographic separation and injection into an Isotope Ratio Mass Spectrometer (IRMS) (Thermo Finnigan MAT 253). The oxygen isotope ratios were referenced against Vienna Standard Mean Ocean Water (VSMOW) (Baertschi, 1976; Li et al., 1988), whereas ${ }^{15} \mathrm{~N} /{ }^{14} \mathrm{~N}$ was measured against $\mathrm{N}_{2}$-AIR (Mariotti, 1983). All isotopic measurements were corrected using the international reference materials USGS 32, USGS 34 and USGS 35, which 


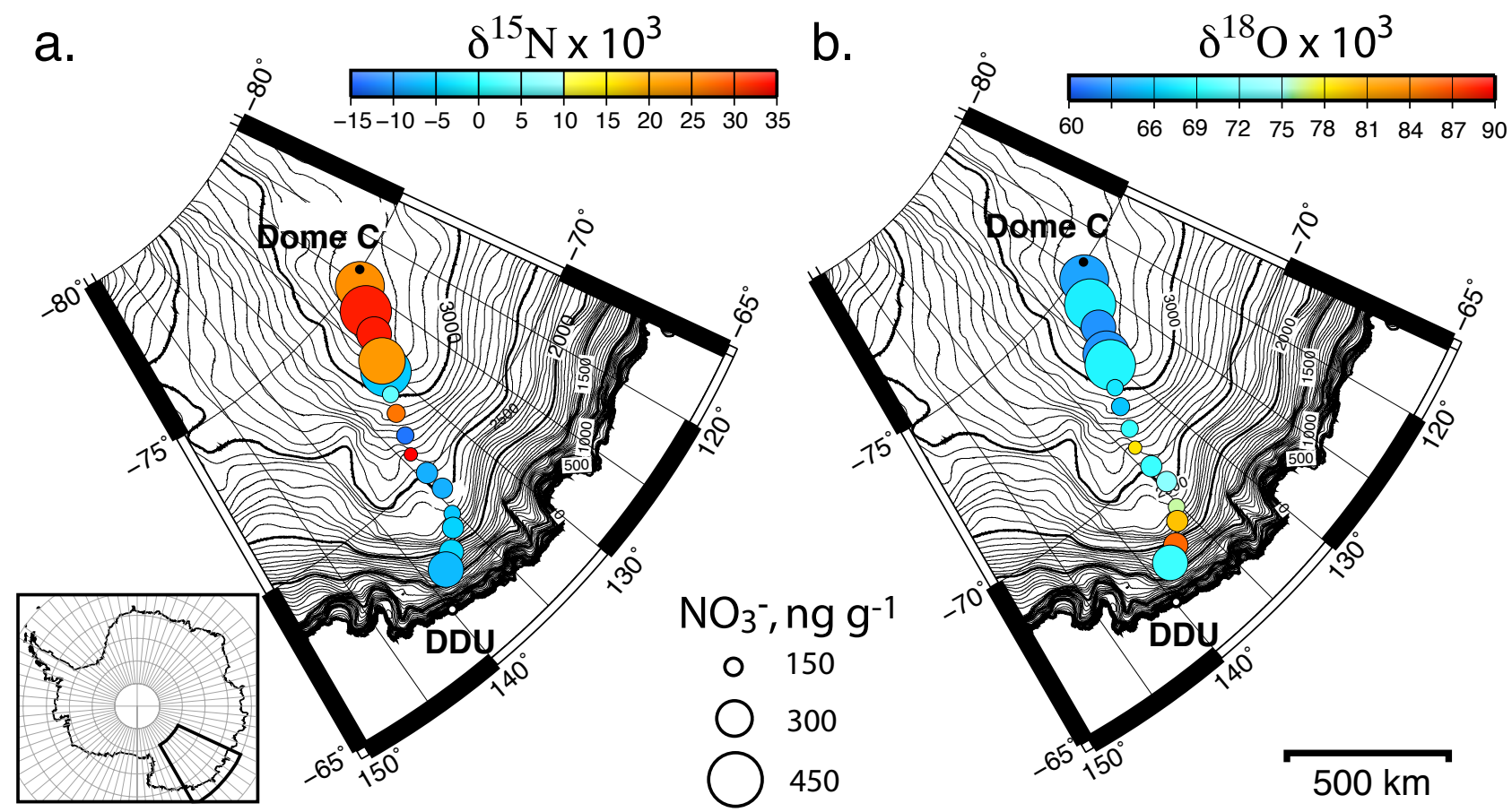

Fig. 2. Spatial distribution of $\delta^{15} \mathrm{~N}\left(\mathrm{NO}_{3}^{-}\right), \delta^{18} \mathrm{O}\left(\mathrm{NO}_{3}^{-}\right)$and $\mathrm{NO}_{3}^{-}$concentrations in surface snow between Dome Concordia and Dumont d'Urville.

are anchored to the VSMOW ( $\mathrm{N}_{2}$-AIR) reference for oxygen (nitrogen) isotopes (Böhlke et al., 2003). The isotope ratios ${ }^{17} \mathrm{O} /{ }^{16} \mathrm{O},{ }^{18} \mathrm{O} /{ }^{16} \mathrm{O}$ and ${ }^{15} \mathrm{~N} /{ }^{14} \mathrm{~N}$ of $\mathrm{NO}_{3}^{-}$are reported as $\delta$ values, where $\delta=\left(R_{\mathrm{spl}} / R_{\mathrm{std}}-1\right)$, with $R$ being the elemental isotope ratios in sample and standard, respectively. The oxygen isotope anomaly of $\mathrm{NO}_{3}^{-}$is here defined by its linear approximation as $\Delta^{17} \mathrm{O}=\delta^{17} \mathrm{O}-0.52 \times \delta^{18} \mathrm{O}$. The overall accuracy of the method was calculated as the best estimate for the standard deviation of the residuals from a linear regression between measured standards and their expected values (after Taylor, 1997, p. 187). Reported snow samples have average accuracies of 1.3, 0.6 and $0.4 \%$ and filter samples of $1.4,0.3$ and $0.7 \%$ of $\delta^{18} \mathrm{O}, \Delta{ }^{17} \mathrm{O}$, and $\delta^{15} \mathrm{~N}$, respectively.

\section{Results}

\subsection{Upper snowpack profiles of $\mathrm{NO}_{3}^{-}$}

$\mathrm{NO}_{3}^{-}$concentrations drop in both snow pits within the top $50 \mathrm{~cm}$ to less than $10 \%$ of surface levels ranging from 240 to $325 \mathrm{ng} \mathrm{g}^{-1}$ (Fig. 1c). $\quad \delta^{15} \mathrm{~N}\left(\mathrm{NO}_{3}^{-}\right)$values increase by $>200 \%$ whereas $\delta^{18} \mathrm{O}\left(\mathrm{NO}_{3}^{-}\right)$levels decrease by $20-40 \%$ o within the top $70 \mathrm{~cm}$ resulting in a statistically significant anti-correlation between the two isotopic ratios $(r=-0.9$, $p<0.001$ ) (Fig. 1b, c). The $\Delta^{17} \mathrm{O}\left(\mathrm{NO}_{3}^{-}\right)$profile exhibits periodic oscillations with an amplitude of 4-5\%o (Fig. 1a), found also in two additional snow pits (Frey et al., 2009). Comparison of the top and bottom values of $\Delta^{17} \mathrm{O}\left(\mathrm{NO}_{3}^{-}\right)$in both snow pits reveals a decreasing trend of more than $4 \%$, from 28 to $24 \%$ in 2004 and from 32 to $27 \%$ in 2007 (Fig. 1a).

$\mathrm{NO}_{3}^{-}$concentrations in surface snow between DC and DDU range from 112 to $435 \mathrm{ng} \mathrm{g}^{-1}$, with maxima occurring on the East Antarctic plateau (Fig. 2). $\delta^{15} \mathrm{~N}\left(\mathrm{NO}_{3}^{-}\right)$varies between -13 and $37 \%$, and shows a strong spatial gradient from negative values below 2700 m.a.m.s.l. ( -8 to $-4 \%$ ) to positive isotope ratios on the plateau above 3000 m.a.m.s.l. (22-34\%o), with a transition zone of high variability (Fig. 2a). $\delta^{18} \mathrm{O}\left(\mathrm{NO}_{3}^{-}\right)$exhibits also a spatial gradient but weaker and of opposite sign, with low isotope ratios on the East Antarctic plateau of $<65 \%$ and high levels of $>75 \%$ o towards the coast (Fig. 2b). However, the spatial correlation between the two isotopic ratios is not significant $(r=-0.4, p<0.2)$. The average $\pm 1 \sigma$ of $\Delta^{17} \mathrm{O}\left(\mathrm{NO}_{3}^{-}\right)$is $30 \pm 3 \%$ and no significant spatial trend is detected (data not shown).

\subsection{Annual cycle of atmospheric $\mathrm{NO}_{3}^{-}$}

Average ( $\pm 1 \sigma)$ levels in atmospheric $\mathrm{NO}_{3}^{-}$between February and July 2007 are $4.5( \pm 3.8) \mathrm{ng} \mathrm{m}^{-3}$, with local maxima in late winter (August-September) of $50 \mathrm{ng} \mathrm{m}^{-3}$ and in summer (December-January) of $142 \mathrm{ng} \mathrm{m}^{-3}$, very similar to the coastal record at DDU in 2001 (Savarino et al., 2007) (Fig. 3b). The annual cycles of $\delta^{18} \mathrm{O}\left(\mathrm{NO}_{3}^{-}\right)$and $\Delta^{17} \mathrm{O}\left(\mathrm{NO}_{3}^{-}\right)$ compare well to those observed at DDU and South Pole (McCabe et al., 2007; Savarino et al., 2007), showing broad maxima in late winter and early spring of $>100 \%$ and 
$>40 \%$ o, respectively (Fig. 3d, e). The annual variability of $\delta^{15} \mathrm{~N}\left(\mathrm{NO}_{3}^{-}\right)$features moderate oscillations between -7 and $13 \%$ around a February-July mean of $4 \%$ o but interrupted by a gradual decrease starting at the end of August as surface temperatures and UV radiation begin to rise, reaching strongly negative values with a minimum of $-35 \%$ in midOctober, followed by a recovery to the February-July average by December (Fig. 3a, c). While April-October levels are almost indistinguishable between DC in 2007 and DDU in 2001 and similar to those at Neumayer station observed during the 1986-1992 period (Wagenbach et al., 1998), coastal $\delta^{15} \mathrm{~N}\left(\mathrm{NO}_{3}^{-}\right)$remains negative throughout the summer months and no recovery occurs as seen at DC (Fig. 3c).

\section{Discussion}

\subsection{Post-depositional isotopic fractionation}

The DC07 $\mathrm{NO}_{3}^{-}$snow profile is similar to those published previously, showing $>90 \% \mathrm{NO}_{3}^{-}$loss in the top $10 \mathrm{~cm}$ (Röthlisberger et al., 2000; Blunier et al., 2005; Traversi et al., 2009), whereas in $2004 \mathrm{NO}_{3}^{-}$concentrations exhibit a more gradual decline with depth (Fig. 1c). Spatial variability in concentration profiles can be considerable at DC (Traversi et al., 2009; Frey et al., 2009) and is attributed to sastrugi formation and wind drift in the vicinity of the station. Regardless of the $\mathrm{NO}_{3}^{-}$profile, trends with depth of $\mathrm{NO}_{3}^{-}$stable isotopes are similar in pits sampled in different years (Fig. 1). Some of the most extreme $\delta^{15} \mathrm{~N}\left(\mathrm{NO}_{3}^{-}\right)$values found so far in polar snow and ice are observed, exceeding the -18 to $200 \%$ o range previously reported (Freyer et al., 1996; Heaton et al., 2004; Hastings et al., 2004; Blunier et al., 2005). $\delta^{18} \mathrm{O}\left(\mathrm{NO}_{3}^{-}\right)$ in surface snow from pit and spatial survey samples ranges between 55 and $85 \%$ and thus overlaps with measurements in the high Arctic and Greenland (Heaton et al., 2004; Hastings et al., 2004), but drops at depth to values below $30 \%$ o (Figs. 1b, 2b). $\Delta^{17} \mathrm{O}\left(\mathrm{NO}_{3}^{-}\right)$in snow pit and spatial survey samples varies between 24 and 36\%o (Fig. 1a), a range similar to measurements in snow pits from South Pole and Summit, Greenland (McCabe et al., 2007; Kunasek et al., 2008).

Most importantly, snow profiles of $\delta^{15} \mathrm{~N}\left(\mathrm{NO}_{3}^{-}\right)$show strong enrichment, whereas $\delta^{18} \mathrm{O}\left(\mathrm{NO}_{3}^{-}\right)$is depleted compared to the isotopic signal in atmospheric $\mathrm{NO}_{3}^{-}$. The isotopic atmospheric input above the Antarctic ice sheet shows spatial but no temporal variability during the past decade (Fig. 3c-e) and pit profiles of the top $0.7 \mathrm{~m}$ of snow, equivalent to about $10 \mathrm{yr}$, sampled in different years overlap (Fig. 1). From this we conclude that post-depositional isotopic fractionation and not atmospheric trends control $\delta^{15} \mathrm{~N}$ and $\delta^{18} \mathrm{O}$ in $\mathrm{NO}_{3}^{-}$at low-accumulation sites such as DC, leading to reproducible profiles as long as the boundary conditions remain unchanged. In the case of $\Delta^{17} \mathrm{O}\left(\mathrm{NO}_{3}^{-}\right)$ post-depositional fractionation is significant, e.g. loss of the winter/spring maximum of $>40 \%$ o in atmospheric $\mathrm{NO}_{3}^{-}$

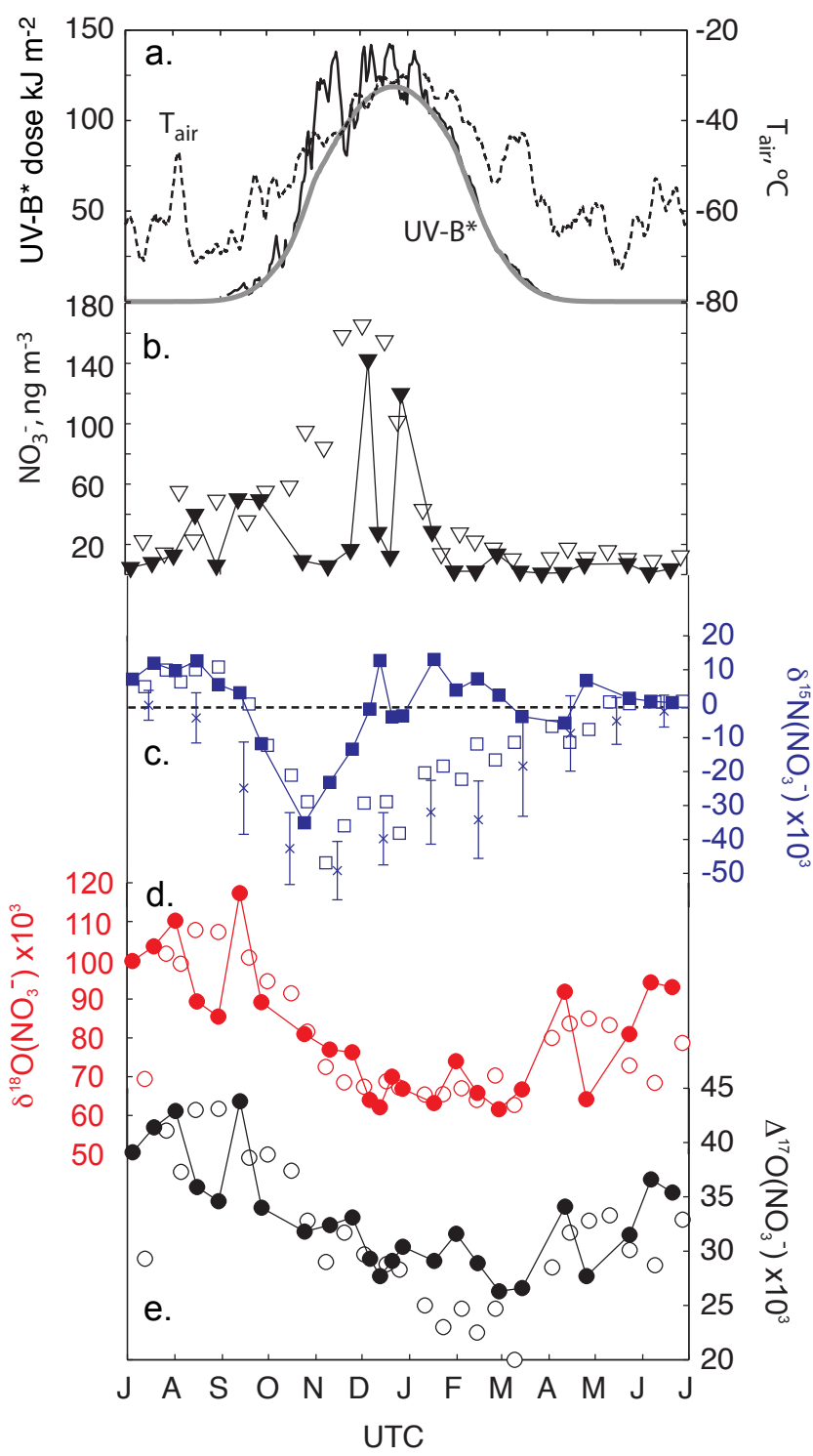

Fig. 3. Atmospheric $\mathrm{NO}_{3}^{-}$at $\mathrm{DC}$ in 2007 and coastal records at DDU (Savarino et al., 2007) and Neumayer (NM) (Wagenbach et al., 1998): (a) DC air temperature and modeled daily UV-B (280$320 \mathrm{~nm}$ ) for observed and a constant (290 DU) $\mathrm{O}_{3}$ column density (black and grey lines) (b) $\mathrm{NO}_{3}^{-}$concentrations, (c) $\delta^{15} \mathrm{~N}\left(\mathrm{NO}_{3}^{-}\right)$, (d) $\delta^{18} \mathrm{O}\left(\mathrm{NO}_{3}^{-}\right)$and (e) $\Delta^{17} \mathrm{O}\left(\mathrm{NO}_{3}^{-}\right)$at DC and DDU in 2001 (closed and open symbols, respectively). Cross symbols in (c) are mean $\delta^{15} \mathrm{~N}\left(\mathrm{NO}_{3}^{-}\right)$at $\mathrm{NM}$ from $1986-1992$ and errorbars the $1-\sigma$ interannual variability.

(Fig. 3e), but less severe across the top $0.7 \mathrm{~m}$ (Fig. 1a). Postdepositional effects in the upper snowpack erase any seasonal signal in $\mathrm{NO}_{3}^{-}$concentrations and isotopic composition (Figs. 1, 3). This is consistent with the general observation that at sites of low annual accumulation rates the seasonality in many chemical parameters is lost (e.g. Frey et al., 2006). A contributing factor is physical redistribution of surface-near 


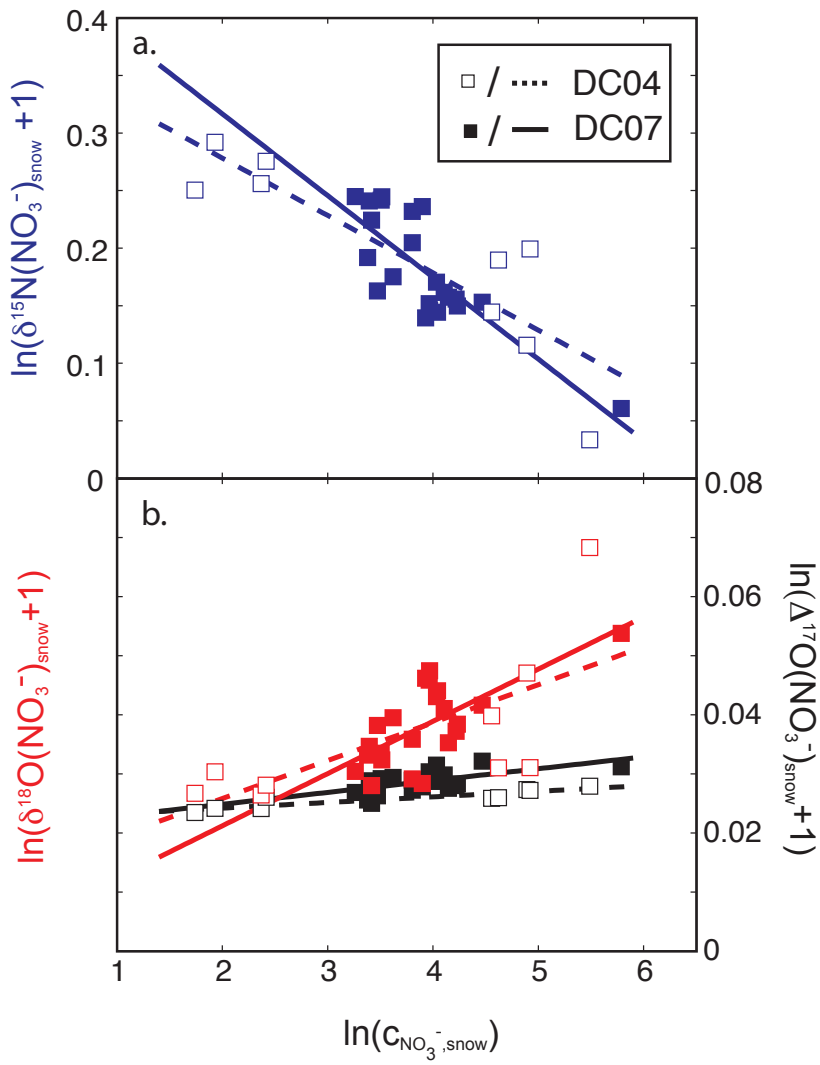

Fig. 4. Rayleigh model fit to observations of $\Delta^{17} \mathrm{O}, \delta^{18} \mathrm{O}$ and $\delta^{15} \mathrm{~N}$ of $\mathrm{NO}_{3}^{-}$in surface snow at Dome $\mathrm{C}$ to estimate the bulk fractionation constant $\varepsilon$ (Table 1). Error bars are smaller than the symbols and $\mathrm{c}_{\mathrm{NO}_{3}^{-}}$, snow is in $\mathrm{ng} \mathrm{g}^{-1}$.

snow by wind, which can lead to mixing of layers or the loss of an entire annual layer (roughly $10 \mathrm{~cm}$ of snow at DC). The result is smoothing of the atmospheric signal. However, we still find an oscillation in $\Delta^{17} \mathrm{O}\left(\mathrm{NO}_{3}^{-}\right)$with a mean periodicity of 2.3-3.0 yr based on the range of published accumulation rates (Legrand and Delmas, 1988; Röthlisberger et al., 2000) (Fig. 1a). A similar $2.7 \mathrm{yr}$ cycle in $\Delta^{17} \mathrm{O}\left(\mathrm{NO}_{3}^{-}\right)$has been detected previously in a 26 -yr snow pit record at South Pole, where accumulation rate is $8 \pm 3 \mathrm{~g} \mathrm{~cm}^{-2} \mathrm{yr}^{-1}$, almost three times that at DC (e.g. Frey et al., 2006), and was speculated to be linked to stratospheric ozone variability (McCabe et al., 2007).

In order to compare between sites and lab experiments we estimate atmosphere-snow fractionation constants ${ }^{\mathrm{n}} \varepsilon(\mathrm{n}=15$, 17,18 for $\delta^{15} \mathrm{~N}, \Delta^{17} \mathrm{O}$ and $\delta^{18} \mathrm{O}$ in $\mathrm{NO}_{3}^{-}$, respectively) based on a Rayleigh-type process as described previously (Fig. 4, Table 1, Blunier et al., 2005). Note that $\varepsilon$ is related to the commonly used fractionation factor $\alpha$ by $\varepsilon=(\alpha-1)$ (e.g. Criss, 1999). The model assumes that $\mathrm{NO}_{3}^{-}$loss from the snow is irreversible and emitted mass fractions are removed immediately. For clarity we repeat here the equations used by Blunier et al. (2005). The isotope ratio ( $\delta$ value) of the
$\mathrm{NO}_{3}^{-}$mass fraction $f$ remaining in the snow $R_{\text {snow }}\left(\delta_{\text {snow }}\right)$ is related to the initial isotope ratio $R_{0 \text {,snow }}\left(\delta_{0, \text { snow }}\right)$ through the following relationship:

$$
\frac{R_{\text {snow }}}{R_{0, \text { snow }}}=\frac{\delta_{\text {snow }}+1}{\delta_{0, \text { snow }}+1}=f^{\varepsilon}
$$

Regrouping and substitution of $f=c_{\text {snow }} / c_{0, \text { snow }}$, where $c_{0 \text {, snow }}$ is the initial surface snow concentration and $c_{\text {snow }}$ the concentration of fraction $f$ remaining in the snow, lead to expressions which allow to estimate $\varepsilon$ using a linear regression:

$$
\begin{aligned}
& \ln \left(\delta_{\text {snow }}+1\right)=\varepsilon \ln (f)+\ln \left(\delta_{\text {snow }, 0}+1\right) \\
& \ln \left(\delta_{\text {snow }}+1\right)=\varepsilon \ln \left(c_{\text {snow }}\right)+\left[\ln \left(\delta_{\text {snow }, 0}+1\right)-\varepsilon \ln \left(c_{\text {snow }, 0}\right)\right]
\end{aligned}
$$

We find in the DC04 (DC07) pit ${ }^{15} \varepsilon,{ }^{18} \varepsilon$ and ${ }^{17} \varepsilon$ values of $-50 \pm 10(-71 \pm 12) \%$ o, $6 \pm 3(9 \pm 2) \%$ and $1 \pm 0.2(2 \pm 0.6) \%$, respectively (Table 1, Fig. 4). The $1-\sigma$ uncertainties were estimated by propagating the error in the isotopic ratios (Taylor, 1997). Although they are large due to local spatial variability (e.g. Blunier et al., 2005) and sample resolution, it is found that sign and order of magnitude of $\varepsilon$ for the oxygen stable isotopes compare well to those determined in previous lab photolysis experiments (Table 1, Fig. 4). In DC04 the ${ }^{15} \varepsilon$ compares well to the literature value of $-54 \pm 10 \%$ reported for Dome C, whereas in DC07 it falls above the upper end of the cited range of uncertainty (Table 1, Fig. 4).

The observed post-depositional fractionation is attributed to $\mathrm{NO}_{3}^{-}$mass loss from the upper snowpack, as suggested by Blunier et al. (2005) to explain the strong enrichment of $\delta^{15} \mathrm{~N}\left(\mathrm{NO}_{3}^{-}\right)$in snow at DC. Gas phase chemistry cannot be responsible for two reasons. Firstly, reactions which favor nitrate production tend to minimize the fractionation of $\delta^{15} \mathrm{~N}\left(\mathrm{NO}_{3}^{-}\right)$with respect to $\mathrm{NO}_{\mathrm{x}}$, and therefore lead to isotopic ratios close to those of atmospheric $\mathrm{NO}_{\mathrm{x}}$, typically ranging between -9 and $13 \%$ (Heaton et al., 2004). And secondly, strongly positive $\delta^{15} \mathrm{~N}\left(\mathrm{NO}_{3}^{-}\right)$values have never been observed in atmospheric $\mathrm{NO}_{3}^{-}$in Antarctica (Wagenbach et al., 1998; Floch, 2006; Savarino et al., 2007, this study Fig. 3c).

$\mathrm{NO}_{3}^{-}$mass loss from snow and therefore isotopic fractionation is thought to be governed by evaporation of $\mathrm{HNO}_{3}$ and $\mathrm{NO}_{3}^{-}$photolysis. The extent of post-depositional processing by either mechanism is in turn controlled by local accumulation rate, temperature, UV radiation and snow physical properties. Wind driven redistribution of surface snow and forced ventilation due to wind pumping may contribute as well, with the latter being less important on a dome with average annual wind speeds of $2.8 \mathrm{~m} \mathrm{~s}^{-1}$. A previous comparison has shown that at wind speeds of $<3 \mathrm{~m} \mathrm{~s}^{-1}$ molecular diffusion rather than forced ventilation from wind pumping determines vertical movement of trace gas chemical species through the open snow pore space (Frey et al., 2005).

Surface snow samples from the DC-DDU traverse indicate to a first order that fractionation increases as annual accumulation rates decrease (accumulation data from Pettre et al., 
Table 1. $\mathrm{NO}_{3}^{-}$stable isotope fractionation constants ${ }^{\mathrm{n}} \varepsilon\left(\mathrm{n}=15,17,18\right.$ for $\delta^{15} \mathrm{~N}, \Delta^{17} \mathrm{O}$ and $\delta^{18} \mathrm{O}$, respectively) observed in surface snow at Dome $\mathrm{C}$ and recent lab photolysis experiments. ${ }^{\mathrm{a}}$

\begin{tabular}{lrrrl}
\hline$T\left({ }^{\circ} \mathrm{C}\right)$ & ${ }^{17} \varepsilon \times 10^{3}$ & ${ }^{18} \varepsilon \times 10^{3}$ & ${ }^{15} \varepsilon \times 10^{3}$ & Reference \\
\hline Dome C & & & & \\
-54 & $0.9 \pm 0.2$ & $6.4 \pm 2.5$ & $-49.8 \pm 10.4$ & DC04 pit (this study) \\
-54 & $2.0 \pm 0.6$ & $8.8 \pm 2.1$ & $-71.0 \pm 11.7$ & DC07 pit (this study) \\
-54 & - & - & $-53.9 \pm 9.7$ & Blunier et al. (2005) \\
Laboratory & & & & \\
$-5^{\mathrm{b}}$ & $5.3 \pm 5.4$ & $6.9 \pm 1.3$ & - & McCabe et al. (2005) \\
$-30^{\mathrm{b}}$ & $1.2 \pm 0.3$ & $7.0 \pm 1.6$ & - & McCabe et al. (2005) \\
$-5^{\mathrm{c}}$ & $-0.2 \pm 0.2$ & $4.8 \pm 4.9$ & - & McCabe et al. (2005) \\
$-30^{\mathrm{c}}$ & $0.3 \pm 0.3$ & $2.2 \pm 0.7$ & - & McCabe et al. (2005) \\
$-20^{\mathrm{d}}$ & - & - & $-11.4 \pm 1.4$ & Blunier et al. (2005) \\
\hline
\end{tabular}

a $1-\sigma$ uncertainties in $\varepsilon$ based on propagation of the error in isotopic ratios (this study, after Taylor, 1997), Monte Carlo analysis (results from Blunier et al., 2005) and standard deviation of all experiments (results from McCabe et al., 2005) .

$\mathrm{b}$ artificial snow of $620 \mu \mathrm{gg}^{-1}$ USGS-35 $\left(\mathrm{NaNO}_{3}\right),>70 \% \mathrm{NO}_{3}^{-}$loss after $12-48 \mathrm{~h}$ irradiation.

$\mathrm{c}$ artificial snow of $620 \mu \mathrm{g} \mathrm{g}^{-1} \mathrm{KNO}_{3},>70 \% \mathrm{NO}_{3}^{-}$loss after $12-48 \mathrm{~h}$ irradiation.

$\mathrm{d}$ artificial snow of $560 \mathrm{ng} \mathrm{g}^{-1} \mathrm{NaNO}_{3}$, max. $90 \% \mathrm{NO}_{3}^{-}$loss after $5 \mathrm{~h}$ irradiation (Jacobi et al., 2006).

1986). $\delta^{15} \mathrm{~N}\left(\mathrm{NO}_{3}^{-}\right)$are negatively correlated with annual accumulation rates $(r=-0.67, p<0.01)$ in agreement with previous findings from Antarctic ice cores (Freyer et al., 1996), whereas $\delta^{18} \mathrm{O}\left(\mathrm{NO}_{3}^{-}\right)$shows a positive correlation $(r=0.68$, $p<0.01) . \mathrm{NO}_{3}^{-}$losses were also observed at South Pole, where surface snow $\mathrm{NO}_{3}^{-}$exceeds all concentration spikes preserved in the $6 \mathrm{~m}$ below (McCabe et al., 2007). The top snow layer, representing the most recent year of snow accumulation, shows a $\Delta^{17} \mathrm{O}\left(\mathrm{NO}_{3}^{-}\right)$of $29.9 \%$ (median of reported max and min values of year round monthly sampling), close to $30.4 \%$ in atmospheric $\mathrm{NO}_{3}^{-}$(median of reported max and min value), whereas at depth $\Delta^{17} \mathrm{O}\left(\mathrm{NO}_{3}^{-}\right)$ is depleted by $4-5 \%$ o similar to our finding at DC (McCabe et al., 2007). At Summit, Greenland, a site with a mean annual accumulation rate of $25 \mathrm{~g} \mathrm{~cm}^{-2} \mathrm{yr}^{-1}$ (Dibb and Fahnestock, 2004), up to $30 \%$ post-depositional loss of $\mathrm{NO}_{3}^{-}$was observed (Dibb et al., 2007). However, according to one study, $\delta^{15} \mathrm{~N}\left(\mathrm{NO}_{3}^{-}\right)$and $\delta^{18} \mathrm{O}\left(\mathrm{NO}_{3}^{-}\right)$did not change significantly over a period of 5 months, the time between initial deposition and burial to $30 \mathrm{~cm}$ depth by subsequent snow fall (Hastings et al., 2004).

Below we discuss in more detail how evaporation and photolysis are expected to shift the signal of stable $\mathrm{NO}_{3}^{-}$isotopes in snow.

\subsection{Mechanisms of isotopic fractionation in snow}

It is instructive to recall what is known about location and chemical form of $\mathrm{NO}_{3}^{-}$within snow grains. $\mathrm{NO}_{3}^{-}$is found not only in the bulk crystal, but is adsorbed also at the top of or dissolved within the so-called quasi liquid layer (QLL) on the grain surface (e.g. Grannas et al., 2007, and references therein). The interplay of various deposition processes determine both, $\mathrm{NO}_{3}^{-}$concentration and distribution within the snow grain in surface snow (Table 2, Röthlisberger et al., 2002). A comparison of $\mathrm{NO}_{3}^{-}$concentration estimates based on different deposition mechanisms shows that a large fraction of $\mathrm{NO}_{3}^{-}$in surface snow at DC in summer can be explained by surface uptake and dry deposition, whereas cocondensation and dissolution in ice rather lead to lower concentrations (Table 2). If these mechanisms dominate, then one would expect that most of the $\mathrm{NO}_{3}^{-}$is located close to the snow grain surface, subject to both evaporative and photolytic loss.

Regarding the chemical form we know that in present-day Antarctica and past interglacials $\mathrm{NO}_{3}^{-}$occurs predominantly as $\mathrm{HNO}_{3}$ as opposed to the salt $\mathrm{Ca}\left(\mathrm{NO}_{3}\right)_{2}$ during glacials (Legrand et al., 1999). It has been suggested that $\mathrm{HNO}_{3}$ newly adsorbed on ice ionizes in a 2-step process,

$$
\mathrm{HNO}_{3, \mathrm{~g}}+\mathrm{H}_{2} \mathrm{O}_{\mathrm{s}} \rightleftharpoons \mathrm{HNO}_{3} \cdot \mathrm{H}_{2} \mathrm{O}_{\mathrm{ad}} \rightleftharpoons \mathrm{NO}_{3, \text { aq }}^{-}+\mathrm{H}_{3} \mathrm{O}_{\mathrm{aq}}^{+}
$$

where subscripts $\mathrm{g}, \mathrm{s}$, ad and aq denote gas, surface, adsorbed and solvated (aqueous) species, respectively (Pursell et al., 2002). Evaporation requires then just reversing Reaction (R6). Molecular dynamics simulations provide support for the notion that nitrate at the air-water interface remains molecular $\mathrm{HNO}_{3}$, whereas it dissociates when embedded at 
Table 2. Estimates of $\mathrm{NO}_{3}^{-}$concentrations in snow at $\mathrm{DC}$ based on different deposition mechanisms. ${ }^{\text {a }}$

\begin{tabular}{lrr}
\hline & summer & winter \\
\hline$T\left({ }^{\circ} \mathrm{C}\right)$ & -30 & -70 \\
$\mathrm{RH}$ & 0.65 & 0.3 \\
$\mathrm{HNO}_{3}(\mathrm{pptv})^{\mathrm{b}}$ & $22(5-68)$ & 1 \\
$\mathrm{NO}_{3}^{-}(\mathrm{ppbw})^{\mathrm{c}}$ & $350->1000$ & 200 \\
& & \\
Co-condensation $^{\mathrm{d}}$ & $80(20-245)$ & 805 \\
Ice solubility $^{\mathrm{d}}$ & $47(25-75)$ & 215 \\
Surface uptake $^{\mathrm{e}}$ & $200(165-235)$ & 350 \\
Dry deposition $^{\mathrm{f}}$ & $225(50-690)$ & 15 \\
\hline
\end{tabular}

a The meteorology data are from the automatic weather station at DC; an average specific surface area of $425 \mathrm{~cm}^{2} \mathrm{~g}^{-1}$ was assumed for snow grains at the surface based on observations by Gallet et al. (2009).

${ }^{\mathrm{b}}$ Due to the lack of data at DC atmospheric concentrations used are from South Pole in summer (Huey et al., 2004) and from Neumayer in winter (Röthlisberger et al., 2000).

${ }^{c}$ Concentrations refer to observations in surface snow at DC, where the upper end of the range in summer represents fresh snow fall (this work and Frey et al., 2009).

$\mathrm{d}$ after Thibert and Domine (1998).

e after Hudson et al. (2002).

${ }^{\mathrm{f}}$ Based on a dry deposition velocity of $0.5 \mathrm{~cm} \mathrm{~s}^{-1}$ (Hauglustaine et al., 1994) and a mean accumulation rate of $3.1 \mathrm{~g} \mathrm{~cm}^{-2} \mathrm{yr}^{-1}$ (Legrand and Delmas, 1988; Röthlisberger et al., 2000).

various depths within the aqueous layer (e.g. Thomas et al., 2007; Wang et al., 2009). The $\mathrm{pH}$ and ionic strength control acid dissociation but are not well characterized in the QLL. However, in the bulk snow crystal we can assume the $\mathrm{pH}$ range of natural waters and an acid dissociation constant $\mathrm{pK}_{a}$ of -1.19 and find that the ionic form dominates with less than $1 \times 10^{-4} \%$ of total nitrate occuring as molecular $\mathrm{HNO}_{3}$. This is important since all forms of nitrate in Reaction (R6) will photolyze, at the surface and very likely also within the snow grain (Dubowski et al., 2001), whereas only molecular $\mathrm{HNO}_{3}$ will evaporate from the surface (Sato et al., 2008).

\subsubsection{Evaporation}

Surface and wind-driven sublimation are important components of the surface mass balance in Antarctica and can remove up to $20 \%$ of annual snowfall at DC (Frezzotti et al., 2004), similar to estimates for the entire ice sheet (Dery and Yau, 2002). While insoluble chemical species will be enriched, volatile species will be removed depending on their volatility.

Summer pit profiles of $\mathrm{NO}_{3}^{-}$concentrations look always similar and concentrations in recent deposition exceed those at depth up to 1-2 orders of magnitude depending on the season (Figs. 1c and 2, Table 2). Significant $\mathrm{NO}_{3}^{-}$mass loss must therefore occur on a seasonal time scale. Surface snow and fresh snowfall at $\mathrm{DC}$ in summer is supersaturated in $\mathrm{NO}_{3}^{-}$ with respect to surface uptake estimated after Hudson et al. (2002) and with respect to the $\mathrm{HNO}_{3}$ solubility in ice (Table 2). In winter all deposition models indicate that snow is undersaturated (Table 2). While supersaturation within the snow grain will lead to redistribution only and no change in concentration, supersaturation at the surface of a snow grain will lead to desorption. It should be noted that the surface coverage model is based on uptake experiments and release might not show the same temperature dependence (Hudson et al., 2002). Previous calculations using results from another surface uptake experiment obtain also significantly higher surface coverage (see details in Röthlisberger et al., 2002).

Regarding the time scales only few experimental data are available. In order to evaluate the redistribution of the $\mathrm{NO}_{3}^{-}$ ion in ice we estimated the ice diffusion constant $D_{0}$ of $\mathrm{HNO}_{3}$ after Thibert and Domine (1998) for summer and annual mean temperature at DC. Assuming typical snow grain radii $r$ of $0.005-0.01 \mathrm{~cm}$ (Gay et al., 2002) we obtain average diffusion times $\tau=r^{2}\left(2 \mathrm{D}_{0}\right)^{-1}$ of $1-3$ weeks and 312 months, respectively, thus still within the seasonal to annual time scale. Recently, evaporation rates of dilute acids were measured above frozen solutions and found to be primarily controlled by the degree of dissociation with vapor pressure being of second order (Sato et al., 2008). This explained that evaporative losses were lowest for highly dissociated acids such as hydrochloric acid $(\mathrm{HCl})$ and not detectable for $\mathrm{HNO}_{3}$ during $96 \mathrm{~h}$ long experiments (Sato et al., 2008). However, in another study dissolution of $\mathrm{HNO}_{3}$ and therefore also release across the air-QLL interface was observed to occur within minutes (Pursell et al., 2002). Thus, from a thermodynamic point of view it is conceivable that temperature-dependent adsorption and desorption contributes to $\mathrm{NO}_{3}^{-}$loss from snow at DC.

No experimental $\varepsilon$ values for the gas-solid-liquid equilibrium phase fractionation of $\mathrm{HNO}_{3}$ are currently available. The only reported lab experiments suggest that fractionation in oxygen stable isotopes from evaporation/sublimation is small, since no change in isotopic ratios was observed when cells filled with snow samples were flushed with helium gas for several hours (McCabe et al., 2005). We therefore attempt a theoretical estimate. According to Reaction (R6) evaporation of $\mathrm{NO}_{3}^{-}$proceeds in two steps, 1) recombination (protonation) to form $\mathrm{HNO}_{3}$ followed by 2) evaporation of $\mathrm{HNO}_{3}$, each of which induce isotopic fractionation. Regarding step 1 we evaluate isotopic exchange equilibria of $\mathrm{HNO}_{3}$ in aqueous solution, considering single oxygen (Reactions $\mathrm{R} 7-\mathrm{R} 8,{ }^{18} \mathrm{O}$ case only) and nitrogen isotope substitution (Reaction R9):

$$
\begin{aligned}
& \mathrm{H}^{18} \mathrm{ONO}_{2}+{ }^{16} \mathrm{ONO}_{2}^{-} \rightleftharpoons \mathrm{H}^{16} \mathrm{ONO}_{2}+{ }^{18} \mathrm{ONO}_{2}^{-} \\
& \mathrm{HON}^{18} \mathrm{OO}+\mathrm{ON}^{16} \mathrm{OO}^{-} \rightleftharpoons \mathrm{HON}^{16} \mathrm{OO}+\mathrm{ON}^{18} \mathrm{OO}^{-} \\
& \mathrm{HO}^{15} \mathrm{NO}_{2}+\mathrm{O}^{14} \mathrm{NO}_{2}^{-} \rightleftharpoons \mathrm{HO}^{14} \mathrm{NO}_{2}+\mathrm{O}^{15} \mathrm{NO}_{2}^{-}
\end{aligned}
$$


According to the statistical mechanical theory of Urey (1947) the ratios of the reduced partition functions $Q$ allow to estimate the respective equilibrium fractionation factors $\alpha$ at thermodynamical equilibrium:

$$
\begin{aligned}
& { }^{18} \alpha_{\mathrm{H}^{18} \mathrm{ONO}_{2} /{ }^{18} \mathrm{ONO}_{2}^{-}}=\frac{Q_{\mathrm{H}^{18} \mathrm{ONO}_{2}} / Q_{\mathrm{H}^{16} \mathrm{ONO}_{2}}}{Q_{18} \mathrm{ONO}_{2}^{-} / Q_{16} \mathrm{ONO}_{2}^{-}} \\
& { }^{18} \alpha_{\mathrm{HON}^{18} \mathrm{OO} / \mathrm{ON}^{18} \mathrm{OO}^{-}}=\frac{Q_{\mathrm{HON}^{18} \mathrm{OO}} / Q_{\mathrm{HON}^{16} \mathrm{OO}}}{Q_{\mathrm{ON}^{18} \mathrm{OO}^{-}} / Q_{\mathrm{ON}^{16} \mathrm{OO}^{-}}} \\
& { }^{15} \alpha_{\mathrm{HO}^{15} \mathrm{NO}_{2} / \mathrm{O}^{15} \mathrm{NO}_{2}^{-}}=\frac{Q_{\mathrm{HO}^{15} \mathrm{NO}_{2}} / Q_{\mathrm{HO}^{14} \mathrm{NO}_{2}}}{Q_{\mathrm{O}^{15} \mathrm{NO}_{2}^{-}} / Q_{\mathrm{O}^{14} \mathrm{NO}_{2}^{-}}}
\end{aligned}
$$

We used previously modeled values of $Q$ (Monse et al., 1969) to calculate the corresponding $\varepsilon$ in the temperature range at Dome $\mathrm{C}$ and find the following: first, oxygen substituted species show both isotopic enrichment and depletion upon protonation, the sign of ${ }^{18} \varepsilon$ depending on the internal molecular position of the rare isotope (Table 3). Assuming a statistical distribution of ${ }^{18} \mathrm{O},{ }^{18} \varepsilon$ values are positive (Table 3 ), but significantly smaller than those observed in the lab and at Dome C (Table 1). Second, nitrogen substituted species show also enrichment in protonated $\mathrm{NO}_{3}^{-}$(Table 3).

To assess the fractionation of the overall process evaporation of the $\mathrm{HNO}_{3}$ molecule (step 2) needs to be also considered. For example, for the hydrogen-bonded oxygen isotope substitution the $\mathrm{HNO}_{3}$ liquid-vapor equilibrium is

$$
\begin{aligned}
& \mathrm{H}^{18} \mathrm{ONO}_{2,(\mathrm{~g})}+\mathrm{H}^{16} \mathrm{ONO}_{2, \text { (aq })} \rightleftharpoons \mathrm{H}^{16} \mathrm{ONO}_{2, \text { (g) }} \\
& +\mathrm{H}^{18} \mathrm{ONO}_{2, \text { (aq) }}
\end{aligned}
$$

Subscripts (g) and (aq) refer to the gaseous and aqueous phase, respectively. $\mathrm{HNO}_{3}$ remaining in the condensed phase is expected to be enriched in the heavy isotopes (e.g. Urey, 1947). While a quantitative ab initio estimate of this equilibrium seems feasible, it is beyond the scope of this work (e.g. Oi, 2003).

In summary, evaporation/sublimation should deplete both the heavy oxygen and nitrogen isotopes in the $\mathrm{NO}_{3}^{-}$ion remaining in the snow phase, provided that the aqueous phase equilibrium is the controlling step in the overall fractionation. In this case, the strong enrichment of the nitrogen isotopes observed in natural snow (Table 1) indicates that evaporation plays only a minor role in post-depositional fractionation. We note that lab experiments are needed to confirm this model.

\subsubsection{Photolysis}

We evaluate photolytic fractionation by applying the theory of photo-induced isotopic fractionation effects (PHIFE) (Miller and Yung, 2000). This general framework was originally developed to explain enrichment of all the rare heavy isotopologues observed in stratospheric $\mathrm{N}_{2} \mathrm{O}$, a molecule whose main sink is photodissociation (Yung and Miller,
Table 3. Reduced partition function ratios (RPFR) modeled by Monse et al. (1969) were used to calculate $\varepsilon$ for $\mathrm{HNO}_{3}$ exchange equilibria in the temperature range typical for Dome $\mathrm{C}$.

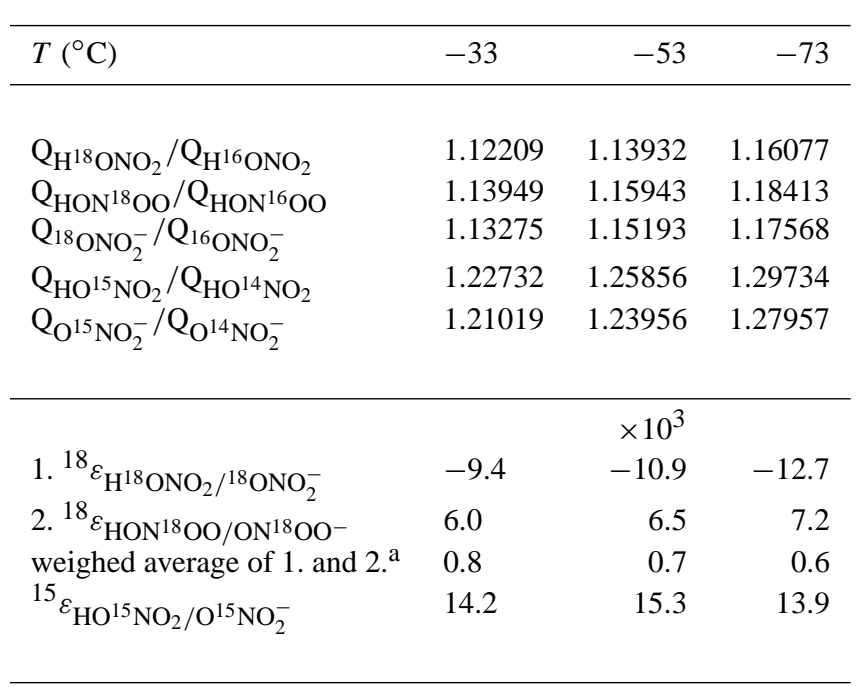

${ }^{a}$ assuming a statistical distribution of ${ }^{18} \mathrm{O}$

1997). The physical principal underlying PHIFE is that every isotopologue has its unique spectroscopic signature. Substitution of an atom by its heavier isotope causes an increase in reduced mass and therefore a red shift in the vibrational frequencies and a reduction in zero point energy (ZPE) of the molecule (Miller and Yung, 2000). This explains small blue shifts and narrowing of UV absorption peaks of the heavier isotopologues, which in turn lead to measurable differences in isotopic fractionation (Miller and Yung, 2000).

As often the case, experimental spectral data on the heavy isotopologues are not available. Instead, UV-absorption spectra can be estimated through ab initio calculations or employing the $\triangle$ ZPE-shift model (Yung and Miller, 1997; Miller and Yung, 2000). The latter consists in applying a uniform blue shift to measured spectral absorptivities by the difference in ZPE between the respective isotopologues (Yung and Miller, 1997). $\triangle \mathrm{ZPE}$ is calculated using $\mathrm{ZPE}=0.5 \sum v_{\mathrm{i}}$, where $v_{\mathrm{i}}$ refers to the normal vibration frequencies (e.g. Criss, 1999).

The smooth and continuous UV absorption spectrum of aqueous $\mathrm{NO}_{3}^{-}$makes it amenable to the $\triangle \mathrm{ZPE}$-shift model (Fig. 5a; Chu and Anastasio, 2003). However, limitations of the $\triangle \mathrm{ZPE}$-shift model are that it does not account for changes in shape and intensity of absorption spectra upon isotopic substitution (Miller and Yung, 2000). Furthermore, the underlying assumptions of direct photo-dissociation and unit quantum yield (Miller and Yung, 2000) are likely not met by $\mathrm{NO}_{3}^{-}$in snow. The quantum yield of the major photolysis channel of $\mathrm{NO}_{3}^{-}$on ice estimated after Chu and Anastasio (2003) is only about $1.89 \times 10^{-3}$ at $-30^{\circ} \mathrm{C}$. Despite these 


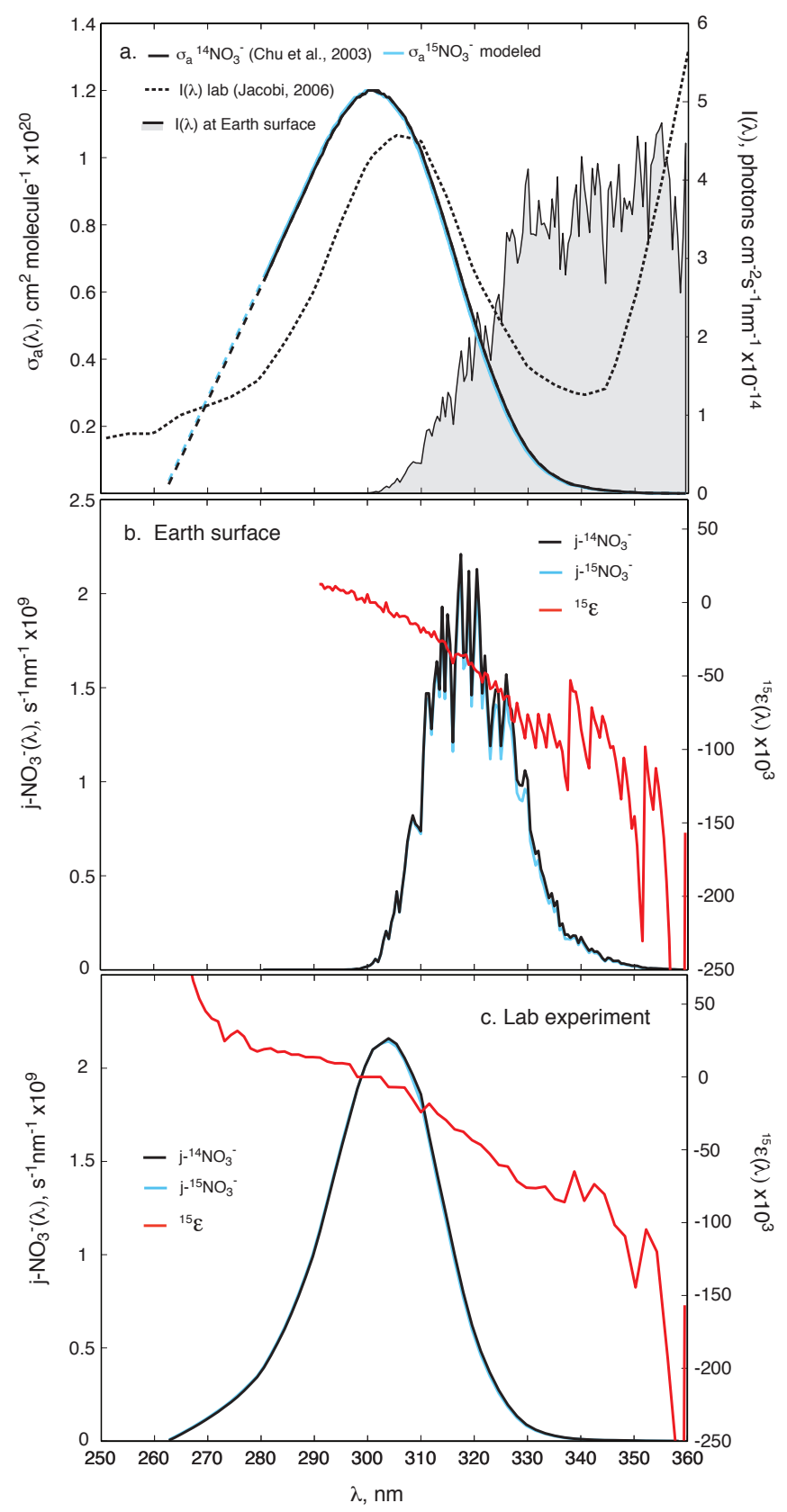

Fig. 5. Photoinduced fractionation effects (PHIFE) of $\delta^{15} \mathrm{~N}\left(\mathrm{NO}_{3}^{-}\right)$: (a) UV absorption spectra of aqueous ${ }^{14} \mathrm{NO}_{3}^{-}$(Chu and Anastasio, 2003, dashed line represents extrapolation of measurements) and ${ }^{15} \mathrm{NO}_{3}^{-}$(estimated with the $\triangle \mathrm{ZPE}$-shift model) are shown with spectral actinic flux at the Earth surface (see text) and in a previous lab photolysis experiment (Jacobi et al., 2006). Photolysis rates $j$ for both $\mathrm{NO}_{3}^{-}$isotopologues allow to calculate the photolytic fractionation constant ${ }^{15} \varepsilon$ (Eqs. 8-9), here shown as a function of wavelength. $j(\lambda)$ and ${ }^{15} \varepsilon(\lambda)$ representative for conditions at the Earth surface (b) are contrasted to those calculated for the UV-lamp in the reported lab experiment (c). limitations affecting the accuracy of the estimated absorption spectra this approach should still give a first estimate of photolytic fractionation.

Convolution of spectral actinic flux $I(\lambda)$, quantum yield $\phi_{a}(\lambda)$ and the respective spectral UV absorptivity $\sigma_{a}(\lambda)$ yields photolysis rate $j$ for each isotopologue

$j=\int \sigma_{a}(\lambda) \phi_{a}(\lambda) I(\lambda) d \lambda$

The photolytic fractionation constant for each isotopologue pair is then given by the ratio of the respective photolysis rates

$\varepsilon=\left(j^{\prime} / j\right)-1$

Figure 5 illustrates Eqs. (8)-(9) taking the calculation of ${ }^{15} \varepsilon$ as an example. Below we discuss the cases of the nitrogen and oxygen stable isotopes for conditions at Dome $\mathrm{C}$ in January 2004. $I(\lambda)$ at the Earth surface was computed with the radiation transfer model TUV4.4 (http://www.acd. ucar.edu/TUV, Madronich and Flocke, 1998) taking into account elevation and January temperature at DC. The calculated spectrum showed close agreement with recent field measurements (J. L. France, personal communication, 2008). Quantum yield $\phi_{a}$ at $-30^{\circ} \mathrm{C}$ from above was assumed to be constant for all wavelengths.

$\delta^{15} \mathbf{N}$

Vibrational frequencies of ${ }^{14} \mathrm{NO}_{3}^{-}$and ${ }^{15} \mathrm{NO}_{3}^{-}$were determined previously by measurement and $a b$ initio calculations and show close agreement (Table 4, Begun and Fletcher, 1960; Monse et al., 1969). Based on these we derived a $\triangle \mathrm{ZPE}$ of $-44.8 \mathrm{~cm}^{-1}$, equivalent to an average blueshift of $0.5 \mathrm{~nm}$ in the $280-360 \mathrm{~nm}$ region (Fig. 5a, Table 4). Photolysis rates for ${ }^{14} \mathrm{NO}_{3}^{-}$and ${ }^{15} \mathrm{NO}_{3}^{-}$are 7.65 and $7.29 \times 10^{-8} \mathrm{~s}^{-1}$, respectively (Fig. 5b). The resulting ${ }^{15} \varepsilon$ of $-48 \%$ is close to bulk fractionation constants derived from pit profiles (Fig. $5 \mathrm{c}$, Tables 1, 4). Examination of the spectral $\varepsilon(\lambda)$ shows that below $302 \mathrm{~nm}$ depletion should occur, however due to the nature of $I(\lambda)$ enrichment dominates (Fig. 5b).

These estimates are significantly larger than the reported ${ }^{15} \varepsilon$ value of $-11 \%$ o derived from lab photolysis experiments (Table 1, Blunier et al., 2005). In these experiments artificial snow made from dilute solutions of $\mathrm{NaNO}_{3}$ was used (Jacobi et al., 2006), but additional experiments replacing $\mathrm{NaNO}_{3}$ with $\mathrm{HNO}_{3}$ did not indicate any significant changes in the observed decrease of $\mathrm{NO}_{3}^{-}$concentrations upon irradiation (H. W. Jacobi, personal communication, 2008). Since fractionation is related to mass loss the same should apply also to ${ }^{15} \varepsilon$.

However, we suspect that ${ }^{15} \varepsilon$ was significantly underestimated by Blunier et al. (2005) due to the experimental set up employed. First, irradiated snow samples were kept in closed cells and therefore photolysis products $\mathrm{NO}_{2}$ and $\mathrm{OH}$ not flushed from the cell likely participated in reformation 
Table 4. Normal vibrational frequencies $v_{\mathrm{i}}$ of $\mathrm{NO}_{3}^{-}$isotopologues used to calculate photolytic fractionation constants $\varepsilon$.

\begin{tabular}{llrrrr}
\hline & $\mathrm{NO}_{3}^{-\mathrm{a}}$ & ${ }^{15} \mathrm{NO}_{3}^{-\mathrm{a}}$ & \multicolumn{1}{c}{$\mathrm{NO}_{3}^{-\mathrm{b}}$} & ${ }^{15} \mathrm{NO}_{3}^{-\mathrm{b}}$ & $\mathrm{N}^{18} \mathrm{OO}_{2}^{-\mathrm{b}}$ \\
\hline$v_{\mathrm{i}}\left(\mathrm{cm}^{-1}\right)$ & & & & & \\
$\nu_{1}$ & 1049.2 & 1049.2 & 1049.5 & 1049.5 & 1029.2 \\
$\nu_{2}$ & 830.9 & 809.0 & 831.0 & 809.3 & 827.5 \\
$\nu_{3}$ & 1375.6 & 1343.7 & 1375.9 & 1344.1 & 1361.2 \\
$\nu_{4}$ & 1375.6 & 1343.7 & 1375.9 & 1344.1 & 1375.6 \\
$\nu_{5}$ & 716.8 & 714.8 & 717.1 & 714.9 & 700.7 \\
$\nu_{6}$ & 716.8 & 714.8 & 717.1 & 714.9 & 707.9 \\
\hline $\mathrm{ZPE}\left(\mathrm{cm}^{-1}\right)$ & 3032.5 & 2987.6 & 3033.2 & 2988.4 & 3001.0 \\
$\Delta \mathrm{ZPE}\left(\mathrm{cm}^{-1}\right)$ & & -44.8 & & -44.8 & -32.1 \\
$\varepsilon \times 10^{3} \mathrm{at} \mathrm{DC}^{\mathrm{c}}$ & & -47.6 & & -47.6 & -34.2 \\
$\varepsilon \times 10^{3} \mathrm{Lab}$ & & $-4.7^{\mathrm{d}}$ & & $-4.7^{\mathrm{d}}$ & $-17.7^{\mathrm{e}}$ \\
\hline
\end{tabular}

a aqueous phase observations (Begun and Fletcher, 1960).

$\mathrm{b}$ model calculations, no solvent included (Monse et al., 1969).

${ }^{\mathrm{c}}$ with $I(\lambda)$ modeled for conditions at DC in January 2004 (see text).

$\mathrm{d}$ with $I(\lambda)$ of the UV lamp used in lab photolysis experiments by Jacobi et al. (2006) (see text).

e with $I(\lambda)$ of the UV lamp used by McCabe et al. (2005).

and deposition of $\mathrm{NO}_{3}^{-}$, thereby reducing isotopic fractionation (Jacobi et al., 2006). $\mathrm{NO}_{3}^{-}$reformation is consistent with $\mathrm{NO}_{3}^{-}$concentrations never dropping below $10 \%$ of the starting levels, even after prolonged irradiation (Jacobi et al., 2006). Second, the UV spectrum of the lamp used is significantly different from that of the sun at the Earth surface. It shows a secondary maximum around $302 \mathrm{~nm}$ and significant contributions at wavelengths below $280 \mathrm{~nm}$, since no cut-off filters were used (Fig. 5a, Jacobi et al., 2006). As a consequence the photolysis rate spectrum is shifted to shorter wavelengths, where the spectrally resolved ${ }^{15} \varepsilon(\lambda)$ becomes less negative or even positive, equivalent to less enrichment or even depletion (Fig. 5c). The resulting ${ }^{15} \varepsilon$ will therefore be more positive. Indeed, replacing the spectral irradiance for DC with that of the UV lamp used by Jacobi et al. (2006) we obtain ${ }^{15} \varepsilon$ values of $-5 \%$ close to the lab results by Blunier et al. (2005) (Fig. 5a and c, Table 4).

\section{$\delta^{18} O$ and $\Delta^{17} O$}

Using the same approach, we calculate $\varepsilon$ for single oxygen isotope substitution in $\mathrm{NO}_{3}^{-}$using the vibrational frequencies modeled by Monse et al. (1969). We obtain ${ }^{18} \varepsilon$ of -34 and $-18 \%$ under DC and lab conditions (Table 4). Thus, PHIFE predicts enrichment of the heavy oxygen isotopes in $\mathrm{NO}_{3}^{-}$, thereby failing to explain the depletion observed in the field and lab (Tables 1, 4).

As opposed to ${ }^{15} \mathrm{~N}$ we argue that oxygen stable isotopes will be affected by not only photolysis but also matrix effects. Previous lab photolysis experiments using isotopically labeled water suggested that oxygen isotope depletion is the result of isotopic exchange with reservoirs depleted in heavy oxygen during secondary $\mathrm{NO}_{3}^{-}$formation (McCabe et al., 2005). Photolytically formed $\mathrm{NO}_{2}$ and $\mathrm{NO}$ (Reactions R1$\mathrm{R} 4)$ are reoxidized in aqueous phase reactions with the $\mathrm{OH}$ radical, produced mostly from $\mathrm{H}_{2} \mathrm{O}_{2}$ photolysis (Anastasio et al., 2007), and water, e.g. in the QLL, to $\mathrm{NO}_{3}^{-}$and $\mathrm{NO}_{2}^{-}$, respectively. $\delta^{18} \mathrm{O}\left(\mathrm{H}_{2} \mathrm{O}\right)$ of Antarctic snow is $<-40 \%$ o (Masson-Delmotte et al., 2008) and $\delta^{18} \mathrm{O}$ of the $\mathrm{OH}$ radical likely similar due to rapid exchange with $\mathrm{H}_{2} \mathrm{O}$ in the aqueous phase (Meijer and $\mathrm{Li}, 1998$ ). Isotopic exchange with $\mathrm{OH}$ and $\mathrm{H}_{2} \mathrm{O}$ is also consistent with the decrease of $\Delta^{17} \mathrm{O}\left(\mathrm{NO}_{3}^{-}\right)$ since both reservoirs have $\Delta^{17} \mathrm{O}$ close to zero (McCabe et al., 2005 , and references therein).

According to this model photolysis can explain ${ }^{15} \varepsilon$ values observed in the field and in lab experiments, where evaporation/sublimation was minimal or not occuring at all. Taking into account the aforementioned limitations of the $\triangle \mathrm{ZPE}-$ shift model and assuming that isotopic substitution leads to a decrease in intensity and narrowing of the UV-absorption peak, the calculated ${ }^{15} \varepsilon$ is likely only an upper estimate of the value typical for conditions at the Earth surface (Fig. 5a). Uncertainties in the respective fractionation constants still prevent a quantitative partitioning into evaporative and photolytic $\mathrm{NO}_{3}^{-}$loss from snow. However, the photolysis model together with the finding that our evaporation model cannot explain the observed enrichment of $\delta^{15} \mathrm{~N}\left(\mathrm{NO}_{3}^{-}\right)$, demonstrates that UV-photolysis is an important process driving $\mathrm{NO}_{3}^{-}$out of the snowpack at DC and very likely across the low accumulation regions of East Antarctica. This has implications for the interpretation of the annual variability of isotopic ratios in atmospheric $\mathrm{NO}_{3}^{-}$(Fig. 3) and atmospheresnow cycling of $\mathrm{NO}_{3}^{-}$above the EAIS, as discussed below. 


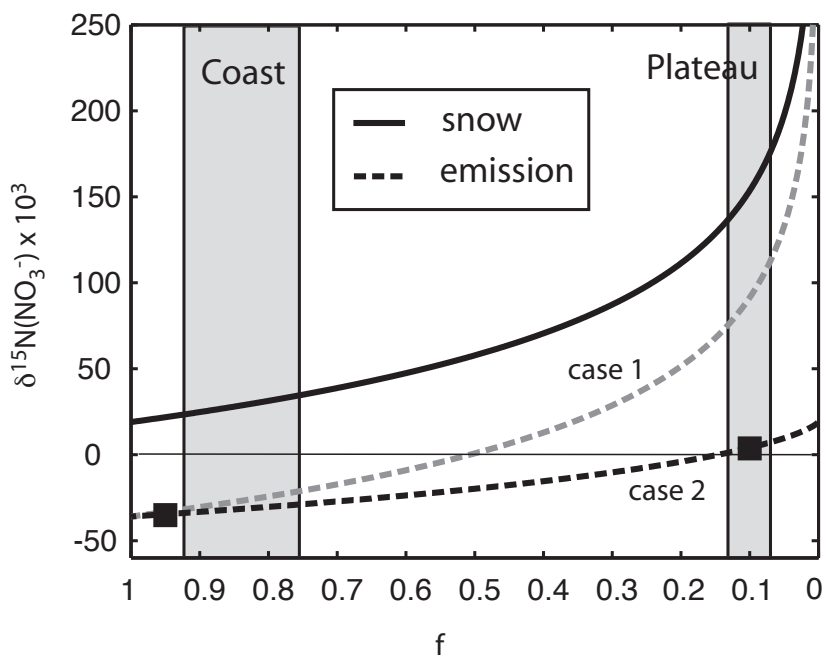

Fig. 6. Modeled $\delta^{15} \mathrm{~N}\left(\mathrm{NO}_{3}^{-}\right)$in snow and emissions against the remaining $\mathrm{NO}_{3}^{-}$mass fraction in snow. Squares represent atmospheric $\mathrm{NO}_{3}^{-}$measured at DC in October and December 2007. Expected $\mathrm{NO}_{3}^{-}$losses in the study area (areas shaded in grey) are based on annual accumulation rate (Blunier et al., 2005; Dibb et al., 2007). Emission scenarios considered are immediate removal after release (case 1) and accumulation of emissions above the local snow surface, equivalent to the integration of all emissions from case 1 (case 2).

\section{3 $\mathrm{NO}_{3}^{-}$recycling above snow in Antarctica}

In Antarctica, primary $\mathrm{NO}_{3}^{-}$sources are thought to be sedimentation of polar stratospheric clouds (PSCs) in late winter and a background tropospheric source from lightning, biomass burning and the ocean (Wagenbach et al., 1998; Savarino et al., 2007). On the one hand, the spring maximum of atmospheric $\mathrm{NO}_{3}^{-}$concentrations observed on the coast and now also inland (Fig. 3b) was recently attributed to a stratospheric source based on the $\Delta^{17} \mathrm{O}\left(\mathrm{NO}_{3}^{-}\right)$signature (Fig. 3e, Savarino et al., 2007). On the other hand, it has been suggested that the coastal summer maximum of $\mathrm{NO}_{3}^{-}$ concentrations (Fig. 3b) has its origin in reoxidized snow emissions of reactive nitrogen advected from the interior of Antarctica (Savarino et al., 2007). This was based on the argument that surface snow enrichment implies emissions depleted in ${ }^{15} \mathrm{~N}\left(\mathrm{NO}_{3}^{-}\right)$along with the observation of strongly negative $\delta^{15} \mathrm{~N}$ in atmospheric $\mathrm{NO}_{3}^{-}$in summer. Strongly negative $\delta^{15} \mathrm{~N}$ in atmospheric $\mathrm{NO}_{3}^{-}$from snow emissions have been observed also in the Weddel sea sector and the Arctic (Morin et al., 2008, 2009).

To understand better the significant difference in the annual cycles of atmospheric $\delta^{15} \mathrm{~N}_{\left(\mathrm{NO}_{3}^{-}\right)}$between $\mathrm{DC}$ and the coast (Fig. 3c) we apply again the Rayleigh model to calculate $\delta^{15} \mathrm{~N}\left(\mathrm{NO}_{3}^{-}\right)$in the snow and emission fraction as a function of $\mathrm{NO}_{3}^{-}$mass loss (Fig. 6, e.g. Criss, 1999). We use an ${ }^{15} \varepsilon$ of $-54 \%$ and as the initial $\delta^{15} \mathrm{~N}\left(\mathrm{NO}_{3}^{-}\right)$in snow a value of
$19 \%$ expected in late winter snow fall from a previous estimate for stratospheric $\mathrm{NO}_{3}^{-}$(Savarino et al., 2007). We consider two emission scenarios, (case 1) immediate removal after release i.e. via horizontal transport and (case 2), accumulation of emissions above the local snow surface, equivalent to the integration of all emissions from case 1 (Fig. 6). Continuous $\mathrm{NO}_{3}^{-}$loss leads to strong isotopic enrichment in the snow fraction consistent with the isotopic ratios found in the upper snowpack (Figs. 6, 1c). However, the profiles of $\mathrm{NO}_{3}^{-}$concentration and $\left.\delta^{15} \mathrm{~N} \mathrm{NO}_{3}^{-}\right)$indicate that $\mathrm{NO}_{3}^{-}$loss is not uniform with depth (Fig. 1c). We therefore suggest the existence of two regions, a skin layer with isotope ratios close to atmospheric equilibrium and high $\mathrm{NO}_{3}^{-}$concentrations and the snowpack underneath strongly depleted in $\mathrm{NO}_{3}^{-}$ and therefore enriched in $\delta^{15} \mathrm{~N}$.

The assumption of isotopic equilibrium at the surface is supported two-fold. First, photolysis playing an important role in $\mathrm{NO}_{3}^{-}$loss from the snowpack implies that reactive nitrogen released to the open snow pore space and atmosphere occurs as $\mathrm{NO}_{\mathrm{x}}$ or $\mathrm{HONO}$, as opposed to gaseous $\mathrm{HNO}_{3}$ in the case of evaporation. Physical interaction with the snow crystal surface will be much smaller for the former than for the latter. Gas phase molecular diffusion with characteristic times on the order of minutes suffices to quickly transfer the photolysis products upward through the firn-air column into the atmosphere above the snow, where eventually all reduced species are oxidized again to $\mathrm{NO}_{3}^{-}$and redeposited to the surface. The photochemical lifetimes of $\mathrm{NO}_{\mathrm{x}}$ and $\mathrm{HNO}_{3}$ in summer above the plateau are short with $\sim 15 \mathrm{~h}$ (Davis et al., 2008) and $3.5 \mathrm{~h}$ (Huey et al., 2004), respectively. This is consistent with rapid recycling at the surface and thereby establishing isotopic equilibrium. Second, $\delta^{15} \mathrm{~N}\left(\mathrm{NO}_{3}^{-}\right)$values in the skin layer at DC in summer are close to those found in atmospheric $\mathrm{NO}_{3}^{-}$(Frey et al., 2009). It should be noted that this is apparently not the case for the top samples in the DC04 and DC07 pits, as they are enriched compared to the atmospheric signal (Figs. 1c, 3c). However, this is due to the chosen sample depth resolution, since collection including snow from below the skin layer (e.g. the top $0.5 \mathrm{~cm}$ ) will necessarily result in increased isotopic ratios. And finally, isotopic equilibrium is also consistent with recent observations at Summit, Greenland, where $\delta^{15} \mathrm{~N}$ in snow $\mathrm{NO}_{3}^{-}$was similar to that in atmospheric $\mathrm{HNO}_{3}$ (Jarvis et al., 2009).

Calculated isotope ratios of emissions in case 2 match best

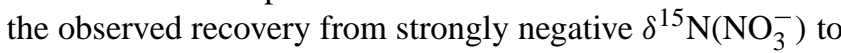
back ground levels in atmospheric $\mathrm{NO}_{3}^{-}$at $\mathrm{DC}$ (Figs. 3c, 6). The exact match with December observations is fortuitous and depends on the initial isotopic ratio chosen for winter snow fall. However, extremely positive $\delta^{15} \mathrm{~N}\left(\mathrm{NO}_{3}^{-}\right)$values as predicted by the case 1 scenario have never been observed. Therefore, we conclude that no significant mass export i.e. by horizontal transport is likely to occur neither at DC nor above the entire EAIS plateau region, where environmental parameters are similar (Figs. 3, 6). One implication of 
minimal $\mathrm{NO}_{3}^{-}$export off the EAIS plateau is that transport strength, a parameter considered to further complicate the interpretation of $\mathrm{NO}_{3}^{-}$ice core records (Wolff et al., 2008), is likely not to play an important role for ice cores recovered from that region.

As discussed above, $\mathrm{NO}_{3}^{-}$loss from the snowpack is much smaller in regions with higher annual accumulation rates (Dibb et al., 2007), including those close to the coast. According to the model $\delta^{15} \mathrm{~N}\left(\mathrm{NO}_{3}^{-}\right)$of emissions remain therefore strongly depleted, consistent with observations during spring and summer at all coastal sites (Figs. 3c, 6). Surface snow collected towards the coast shows also negative $\delta^{15} \mathrm{~N}\left(\mathrm{NO}_{3}^{-}\right)$, as expected from isotopic equilibrium between atmosphere and snow (Fig. 2a). However, it is not possible to distinguish between case 1 and 2, thus leaving open the possibility of $\mathrm{NO}_{3}^{-}$export and emissions from a region reaching as far inland as the $2700 \mathrm{~m}$ contour line could contribute to the DDU summer maximum (Figs. 2a, 6), consistent with the hypothesis stated by Savarino et al. (2007).

\section{Conclusions}

Findings from the first combined atmosphere-snow study of the comprehensive $\mathrm{NO}_{3}^{-}$stable isotopic composition in Antarctica have important implications for our ability to interpret the isotopic signal preserved in snow and ice and our understanding of reactive nitrogen cycling in the low accumulation regions of EAIS.

Profiles of nitrogen (oxygen) stable isotopes of $\mathrm{NO}_{3}^{-}$in surface-near snow at DC show strong enrichment (depletion) compared to the isotopic signal registered in atmospheric $\mathrm{NO}_{3}^{-}$and thus reflect post-depositional fractionation associated with $\mathrm{NO}_{3}^{-}$mass loss rather than atmospheric trends. In contrast, post-depositional effects on $\Delta^{17} \mathrm{O}\left(\mathrm{NO}_{3}^{-}\right)$signal in snow are relatively small. Although the stratospheric source signature and information on seasonal changes in $\mathrm{NO}_{3}^{-}$formation pathways (e.g. Morin et al., 2008) are not preserved, atmospheric trends of lower frequency (e.g. the $2.7 \mathrm{yr}$ cycle) survive post-depositional processing. It therefore seems possible to reconstruct past shifts in tropospheric oxidation pathways from the $\Delta^{17} \mathrm{O}\left(\mathrm{NO}_{3}^{-}\right)$record preserved in ice cores. On the other hand, use of $\delta^{18} \mathrm{O}\left(\mathrm{NO}_{3}^{-}\right)$as a tracer for atmospheric $\mathrm{NO}_{3}^{-}$oxidation pathways (e.g. Hastings et al., 2005; Jarvis et al., 2009) is discouraged, due to its sensitivity to post-depositional fractionation.

We provide strong evidence that UV-photolysis is an important process responsible for $\mathrm{NO}_{3}^{-}$loss from snow. A photochemical model yields an upper estimate for $\delta^{15} \mathrm{~N}\left(\mathrm{NO}_{3}^{-}\right)$ fractionation associated with mass loss, which is applicable not only at DC but at any location at the Earth surface. It shows also that ${ }^{15} \varepsilon$ is very sensitive to the spectrum of actinic flux. Implications are threefold: first, ${ }^{15} \varepsilon$ values based on previous lab experiments are not representative for conditions at the Earth surface, but apply only to the UV lamp used in the experiment (Blunier et al., 2005; Jacobi et al., 2006). Second, the photolytic fractionation constant is process specific and therefore applies not only at DC (e.g. Jarvis et al., 2009) but at any location, including Summit, Greenland. Third, the $\delta^{15} \mathrm{~N}\left(\mathrm{NO}_{3}^{-}\right)$signal preserved in snow and ice should contain information about past changes in UV related to stratospheric ozone or solar variability. We attribute the observed depletion of oxygen stable isotopes in $\mathrm{NO}_{3}^{-}$to matrix effects, which require also $\mathrm{NO}_{3}^{-}$photolysis followed by isotopic exchange between photolysis products and $\mathrm{H}_{2} \mathrm{O}$ and $\mathrm{OH}$. A first estimate of isotopic effects from evaporation is not consistent with the strong enrichment in $\delta^{15} \mathrm{~N}\left(\mathrm{NO}_{3}^{-}\right)$, indicating only a minor contribution to the overall fractionation. Lab experiments are needed to validate the models and to quantify the ratio of photolytic and evaporative mass loss.

As a conceptual model for $\mathrm{NO}_{3}^{-}$recycling in the atmosphere-snow system for DC and the entire EAIS where annual accumulation is low we suggest the following: stratospheric $\mathrm{NO}_{3}^{-}$is deposited to the surface in late winter in a shallow surface snow layer of approximately uniform concentration and $\delta^{15} \mathrm{~N}\left(\mathrm{NO}_{3}^{-}\right)$. The increase in surface UVradiation in spring then initiates a photolysis driven redistribution process of $\mathrm{NO}_{3}^{-}$, which continues throughout the sunlit season resulting in almost complete depletion of the bulk reservoir. This leads then in summer to a strongly asymmetric distribution of total $\mathrm{NO}_{3}^{-}$within the atmosphere-snow column as noted previously (Wolff et al., 2002), with the bulk residing in a skin layer and only a small fraction in the atmospheric column above it.

On going year-round atmosphere-snow studies and summer intensive campaigns at DC will contribute to the development of a quantitative model and specifically address timescales and mass fluxes involved in the $\mathrm{NO}_{3}^{-}$redistribution process. 
Acknowledgements. This work has been made possible thanks to partial support by Institut Paul Émile Victor (IPEV - Programme 1011 NITEDC). Partial funding has also been provided by the National Research Agency of France through project ANR-07VULN-013 VANISH. We thank D. M. Sigman for making available the denitrifier method, E. Vince, A. Déjeant and P. Donnadieu for helping with the lab analysis, B. Jourdain for setting-up the aerosol sampler at DC, DC overwintering staff for taking care of instruments and sample collection, as well as IPEV for providing logistics and PNRA for DC meteorological data. Discussions with C. E. Miller and K. Frey as well as the comments published in ACPD by G. Michalski and one anonymous reviewer were very valuable to further improve this manuscript.

Edited by: T. Röckmann

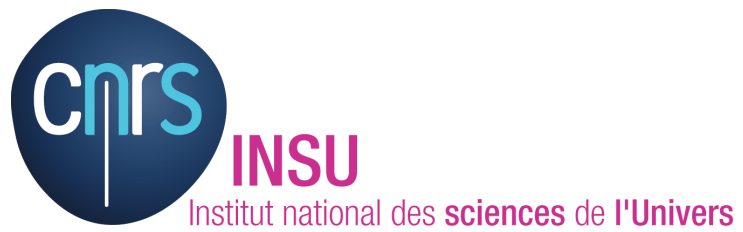

The publication of this article is financed by CNRS-INSU.

\section{References}

Anastasio, C., Galbavy, E. S., Hutterli, M. A., Burkhart, J. F., and Friel, D. K.: Photoformation of hydroxyl radical on snow grains at Summit, Greenland, Atmos. Environ., 41, 5110-5121, 2007.

Baertschi, P.: Absolute ${ }^{18} \mathrm{O}$ content of the Standard Mean Ocean Water, Earth Planet. Sc. Lett., 31(3), 341-344, 1976.

Begun, G. M. and Fletcher, W. H.: Partion function ratios for molecules containing nitrogen isotopes, J. Chem. Phys., 33, 1083-1085, 1960.

Blunier, T., Floch, G. L., Jacobi, H. W., and Quansah, E.: Isotopic view on nitrate loss in Antarctic surface snow, Geophys. Res. Lett., 32, L13501, doi:10.1029/2005GL023011, 2005.

Böhlke, J. K., Mroczkowski, S. J., and Coplen, T. B.: Oxygen isotopes in nitrate: new reference materials for ${ }^{18} \mathrm{O}:{ }^{17} \mathrm{O}:{ }^{16} \mathrm{O}$ measurements and observations on nitrate-water equilibration, Rapid Commun. Mass Sp., 17, 1835-1846, 2003.

Boxe, C. S. and Saiz-Lopez, A.: Multiphase modeling of nitrate photochemistry in the quasi-liquid layer (QLL): implications for $\mathrm{NO}_{\mathrm{x}}$ release from the Arctic and coastal Antarctic snowpack, Atmos. Chem. Phys., 8, 4855-4864, 2008,

http://www.atmos-chem-phys.net/8/4855/2008/.

Casciotti, K. L., Sigman, D. M., Hastings, M. G., Bohlke, J. K., and Hilkert, A.: Measurement of the oxygen isotopic composition of nitrate in seawater and freshwater using the denitrifier method, Anal. Chem., 74, 4905-4912, 2002.

Chu, L. and Anastasio, C.: Quantum yields of hydroxyl radical and nitrogen dioxide from the photolysis of nitrate on ice, J. Phys. Chem. A, 107, 9594-9602, 2003.

Criss, R. E.: Principles of stable isotope distribution, Oxford University Press, 1999.

Davis, D. D., Seelig, J., Huey, G., Crawford, J., Chen, G., Wang, Y. H., Buhr, M., Helmig, D., Neff, W., Blake, D.,
Arimoto, R., and Eisele, F.: A reassessment of Antarctic plateau reactive nitrogen based on ANTCI 2003 airborne and ground based measurements, Atmos. Environ., 42, 2831-2848, doi:10.1016/j.atmosenv.2007.07.039, 2008.

Dery, S. J. and Yau, M. K.: Large-scale mass balance effects of blowing snow and surface sublimation, J. Geophys. Res., 107, 4679, doi:10.1029/2001JD001251, 2002.

Dibb, J. E. and Fahnestock, M.: Snow accumulation, surface height change, and firn densification at Summit, Greenland: Insights from 2 years of in situ observation, J. Geophys. Res., 109, D24113, doi:10.1029/2003JD004300, 2004.

Dibb, J. E., Whitlow, S. I., and Arsenault, M.: Seasonal variations in the soluble ion content of snow at Summit, Greenland: Constraints from three years of daily surface snow samples, Atmos. Environ., 41, 5007-5019, doi:10.1016/j.atmosenv.2006.12.010, 2007.

Dubowski, Y., Colussi, A. J. and Hoffmann, M. R.: Nitrogen dioxide release in the $302 \mathrm{~nm}$ band photolysis of spray-frozen aqueous nitrate solutions, Atmospheric implications, J. Phys. Chem. A, 105, 20, 4928-4932, doi:10.1021/jp0042009, 2001.

Floch, G.: Composition Isotopique du Nitrate dans le Névé Antarctique: Avançées et Nouvelles Perspectives sur les Phénomènes Post-dépôts, Inauguraldissertation der Philosophisch-naturwissenschaftlichen Fakultät der Universität Bern, Abteilung für Klima- und Umweltphysik, Physikalisches Institut der Universität Bern, 2006.

Frey, M. M., Stewart, R. W., McConnell, J. R., and Bales, R. C.: Atmospheric hydroperoxides in West Antarctica: links to stratospheric ozone and atmospheric oxidation capacity, J. Geophys. Res., 110, D23301, doi:10.1029/2005JD006110, 2005.

Frey, M. M., Bales, R. C., and McConnell, J. R.: Climate sensitivity of the century-scale hydrogen peroxide $\left(\mathrm{H}_{2} \mathrm{O}_{2}\right)$ record preserved in 23 ice cores from West Antarctica, J. Geophys. Res., 111, D21301, doi:10.1029/2005JD006816, 2006.

Frey, M. M., Savarino, J., Erbland, J., and Morin, S., Transfer studies of stable isotopes in nitrate in East Antarctica and implications for ice core interpretation, in preparation, 2009.

Freyer, H. D., Kobel, K., Delmas, R. J., Kley, D., and Legrand, M. R.: First results of ${ }^{15} \mathrm{~N} /{ }^{14} \mathrm{~N}$ ratios in nitrate from alpine and polar ice cores, Tellus B, 48, 93-105, 1996.

Frezzotti, M., Pourchet, M., Flora, O., Gandolfi, S., Gay, M., Urbini, S., Vincent, C., Becagli, S., Gragnani, R., Proposito, M., Severi, M., Traversi, R., Udisti, R., and Fily, M.: New estimations of precipitation and surface sublimation in East Antarctica from snow accumulation measurements, Clim. Dynam., 23, 803 813, doi:10.1007/s00382-004-0462-5, 2004.

Gallet, J. C., Arnaud, L., and Domine, F.: Specific surface area of snow at Dome C, Antarctica. Rates of change for timescales from 1 day to 60 years, Geophys. Res. Abstr., EGU2009-4270, 2009.

Gay, M., Fily, M., Genthon, C., Frezzotti, M., Oerter, H., and Winther, J. G.: Snow grain-size measurements in Antarctica, J. Glaciol., 48(163), 527-535, 2002.

Grannas, A. M., Jones, A. E., Dibb, J., Ammann, M., Anastasio, C., Beine, H. J., Bergin, M., Bottenheim, J., Boxe, C. S., Carver, G., Chen, G., Crawford, J. H., Dominé, F., Frey, M. M., Guzmán, M. I., Heard, D. E., Helmig, D., Hoffmann, M. R., Honrath, R. E., Huey, L. G., Hutterli, M., Jacobi, H. W., Klán, P., Lefer, B., McConnell, J., Plane, J., Sander, R., Savarino, J., Shepson, P. B., Simpson, W. R., Sodeau, J. R., von Glasow, R., Weller, R., 
Wolff, E. W., and Zhu, T.: An overview of snow photochemistry: evidence, mechanisms and impacts, Atmos. Chem. Phys., 7, 4329-4373, 2007,

http://www.atmos-chem-phys.net/7/4329/2007/.

Hastings, M. G., Steig, E. J., and Sigman, D. M.: Seasonal variations in $\mathrm{N}$ and $\mathrm{O}$ isotopes of nitrate in snow at Summit, Greenland: Implications for the study of nitrate in snow and ice cores, J. Geophys. Res., 109, D20306, doi:10.1029/2004JD004991, 2004.

Hastings, M. G., Sigman, D. M., and Steig, E. J.: Glacial/interglacial changes in the isotopes of nitrate from the Greenland Ice Sheet Project 2 (GISP2) ice core, Global Biogeochem. Cy., 19, GB4024, doi:10.1029/2005GB002502, 2005.

Hastings, M. G., Jarvis, J. C., and Steig, E. J.: Anthropogenic impacts on nitrogen isotopes of ice-core nitrate, Science, 324, 1288, doi:10.1126/science.1170510, 2009.

Hauglustaine, D. A., Granier, C., Brasseur, G. P., and Megie, G.: The importance of atmospheric chemistry in the calculation of radiative forcing on the climate system, J. Geophys. Res., 99, 1173-1186, 1994.

Heaton, T. H. E., Wynn, P., and Tye, A. M.: Low ${ }^{15} \mathrm{~N} /{ }^{14} \mathrm{~N}$ ratios for nitrate in snow in the High Arctic $\left(79^{\circ} \mathrm{N}\right)$, Atmos. Environ., 38, 5611-5621, doi:10.1016/j.atmosenv.2004.06.028, 2004.

Hudson, P. K., Shilling, J. E., Tolbert, M. A., and Toon, O. B.: Uptake of nitric acid on ice at tropospheric temperatures: Implications for cirrus clouds, J. Phys. Chem. A, 106, 9874-9882, doi:10.1021/jp020508j, 2002.

Huey, L. G., Tanner, D. J., Slusher, D. L., Dibb, J. E., Arimoto, R., Chen, G., Davis, D., Buhr, M. P., and Nowak, J. B.: CIMS measurements of $\mathrm{HNO}_{3}$ and $\mathrm{SO}_{2}$ at the South Pole during ISCAT 2000, Atmos. Environ., 38(32), 5411-5421, doi:10.1016/j.atmosenv.2004.04.037, 2004.

Jacobi, H. W., Annor, T., and Quansah, E.: Investigation of the photochemical decomposition of nitrate, hydrogen peroxide, and formaldehyde in artificial snow, J. Photoch. Photobio. A, 179, 330-338, doi:10.1016/j.jphotochem.2005.09.001, 2006.

Jarvis, J. C., Hastings, M. G., Steig, E. J., Kunasek, S. A.: Isotopic ratios in gas-phase $\mathrm{HNO}_{3}$ and snow nitrate at Summit, Greenland, J. Geophys. Res., 114, D17301, doi:10.1029/2009JD012134, 2009.

Kaiser, J., Hastings, M. G., Houlton, B. Z., Röckmann, T., and Sigman, D. M.: Triple Oxygen Isotope Analysis of Nitrate Using the Denitrifier Method and Thermal Decomposition of $\mathrm{N}_{2} \mathrm{O}$, Anal. Chem., 79, 599-607, doi:10.1021/ac061022s, 2007.

Kunasek, S. A., Alexander, B., Steig, E. J., Hastings, M. G., Gleason, D. J., and Jarvis, J. C.: Measurements and modeling of $\Delta^{17} \mathrm{O}$ of nitrate in snowpits from Summit, Greenland, J. Geophys. Res., 113, D24302, doi:10.1029/2008JD010103, 2008.

Legrand, M. R. and Delmas, R. J.: Soluble impurities in four Antarctic ice cores over the last 30000 years, Ann. Glaciol., 10, 116-120, 1988.

Legrand, M. R., Wolff, E. W., and Wagenbach, D.: Antarctic aerosol and snow fall chemistry: Implications for deep Antarctic ice core chemistry, Ann. Glaciol., 29, 66-72, 1999.

Li, W. J., Ni, B. L., Jin, D. Q., and Zhang, Q. G.: Measurement of the absolute abundance of oxygen-17 in V-SMOW, Kexue Tongbao - Chinese Sci. Bull., 33, 1610-1613, 1988.

Madronich, S. and Flocke, S.: The role of solar radiation in atmospheric chemistry, in: Handbook of Environmental Chemistry, edited by: Boule, P., Springer Verlag, Heidelberg, 1-26, 1998.

Mariotti, A.: Atmospheric nitrogen is a reliable standard for natural ${ }^{15} \mathrm{~N}$ abundance measurements, Nature, 303, 685-687, 1983.

Masson-Delmotte, V., Hou, S., Ekaykin, A., Jouzel, J., Aristarain, A., Bernardo, R. T., Bromwich, D., Cattani, O., Delmotte, M., Falourd, S., Frezzotti, M., Gallee, H., Genoni, L., Isaksson, E., Landais, A., Helsen, M. M., Hoffmann, G., Lopez, J., Morgan, V., Motoyama, H., Noone, D., Oerter, H., Petit, J. R., Royer, A., Uemura, R., Schmidt, G. A., Schlosser, E., Simoes, J. C., Steig, E. J., Stenni, B., Stievenard, M., van den Broeke, M. R., de Wal, R. S. W. V., de Berg, W. J. V., Vimeux, F., and White, J. W. C.: A review of Antarctic surface snow isotopic composition: Observations, atmospheric circulation, and isotopic modeling, J. Climate, 21, 3359-3387, doi:10.1175/2007JCLI2139.1, 2008.

McCabe, J. R., Boxe, C. S., Colussi, A. J., Hoffmann, M. R., and Thiemens, M. H.: Oxygen isotopic fractionation in the photochemistry of nitrate in water and ice, J. Geophys. Res., 110, D15310, doi:10.1029/2004JD005484, 2005.

McCabe, J. R., Thiemens, M. H., and Savarino, J.: A record of ozone variability in South Pole Antarctic snow: Role of nitrate oxygen isotopes, J. Geophys. Res., 112, D12303, doi:10.1029/2006JD007822, 2007.

Meijer, H. A. J. and Li, W. J.: The use of electrolysis for accurate delta $\mathrm{O}-17$ and delta $\mathrm{O}-18$ isotope measurements in water, Isot. Environ. Healt. S., 34, 349-369, 1998.

Miller, C. E. and Yung, Y. L.: Photo-induced isotopic fractionation, J. Geophys. Res., 105(D23), 29039-29051, 2000.

Monse, E. U., Spindel, W., and Stern, M. J.: Analysis of isotope effect calculations illustrated with exchange equilibria among oxynitrogen compounds, in: ACS Advances in Chemistry, 89, 148-184, 1969.

Morin, S., Savarino, J., Bekki, S., Gong, S., and Bottenheim, J. W.: Signature of Arctic surface ozone depletion events in the isotope anomaly $\left(\Delta^{17} \mathrm{O}\right)$ of atmospheric nitrate, Atmos. Chem. Phys., 7 , 1451-1469, 2007, http://www.atmos-chem-phys.net/7/1451/2007/.

Morin, S., Savarino, J., Frey, M. M., Yan, N., Bekki, S., Bottenheim, J. W., and Martins, J. M. F.: Tracing the Origin and Fate of $\mathrm{NO}_{\mathrm{x}}$ in the Arctic Atmosphere Using Stable Isotopes in Nitrate, Science, 322, 730-732, doi:10.1126/science.1161910, 2008.

Morin, S., Savarino, J., Frey, M. M., Domine, F., Jacobi, H.-W., Kaleschke, L., and Martins, J. M. F.: Comprehensive isotopic composition of atmospheric nitrate in the Atlantic Ocean boundary layer from $65 \mathrm{~S}$ to $79 \mathrm{~N}$, J. Geophys. Res., 114, D05303, doi:10.1029/2008JD010696, 2009.

Mulvaney, R. and Wolff, E. W.: Evidence for Winter Spring Denitrification of the Stratosphere in the Nitrate Record of Antarctic Firn Cores, J. Geophys. Res., 98(D3), 5213-5220, 1993.

Mulvaney, R., Wagenbach, D., and Wolff, E. W.: Postdepositional change in snowpack nitrate from observation of year-round near-surface snow in coastal Antarctica, J. Geophys. Res., 103, 11021-11031, 1998.

Oi, T.: Vapor pressure isotope effects of water studied by molecular orbital calculations, J. Nucl. Sci. Technol., 40(7), 517-523, 2003.

Pettre, P., Pinglot, J. F., Pourchet, M., and Reynaud, L.: Accumulation distribution in Terre Adelie, Antarctica - Effect of meteorological parameters, J. Glaciol., 32, 486-500, 1986. 
Pursell, C. J., Everest, M. A., Falgout, M. E., and Sanchez, D. D.: Ionization of nitric acid on ice, J. Phys. Chem. A, 106, 77647768, doi:10.1021/jp025697k, 2002.

Röthlisberger, R., Hutterli, M. A., Sommer, S., Wolff, E. W., and Mulvaney, R.: Factors controlling nitrate in ice cores: Evidence from the Dome C deep ice core, J. Geophys. Res., 105, 2056520572, 2000.

Röthlisberger, R., Hutterli, M. A., Wolff, E. W., Mulvaney, R., Fischer, H., Bigler, M., Goto-Azuma, K., Hansson, M. E., Ruth, U., Siggaard-Andersen, M. L., and Steffensen, J. P.: Nitrate in Greenland and Antarctic ice cores: a detailed description of postdepositional processes, Ann. Glaciol., 35, 209-216, 2002.

Sato, K., Takenaka, N., Bandow, H., and Maeda, Y.: Evaporation loss of dissolved volatile substances from ice surfaces, J. Phys. Chem. A, 112, 7600-7607, 2008.

Savarino, J., Kaiser, J., Morin, S., Sigman, D. M., and Thiemens, M. H.: Nitrogen and oxygen isotopic constraints on the origin of atmospheric nitrate in coastal Antarctica, Atmos. Chem. Phys., 7, 1925-1945, 2007, http://www.atmos-chem-phys.net/7/1925/2007/.

Sigman, D. M., Casciotti, K. L., Andreani, M., Barford, C., Galanter, M., and Bohlke, J. K.: A bacterial method for the nitrogen isotopic analysis of nitrate in seawater and freshwater, Anal. Chem., 73, 4145-4153, 2001.

Silva, S. R., Kendall, C., Wilkison, D. H., Ziegler, A. C., Chang, C. C. Y., and Avanzino, R. J.: A new method for collection of nitrate from fresh water and the analysis of nitrogen and oxygen isotope ratios, J. Hydrol., 228, 22-36, 2000.

Taylor, J. R.: An Introduction to Error Analysis: The study of uncertainties in physical measurements, University Science Books, 2nd edition, 1997.

Thibert, E. and Domine, F.: Thermodynamics and kinetics of the solid solution of $\mathrm{HNO}_{3}$ in ice, J. Phys. Chem. B, 102, 44324439, 1998.
Thomas, J. L., Roeselova, M., Dang, L. X., and Tobias, D. J.: Molecular dynamics simulations of the solution-air interface of aqueous sodium nitrate, J. Phys. Chem. A, 111, 3091-3098, doi:10.1021/jp10683972, 2007.

Traversi, R., Becagli, S., Castellano, E., Cerri, O., Morganti, A., Severi, M., and Udisti, R.: Study of Dome C site (East Antarctica) variability by comparing chemical stratigraphies, Microchem. J., 92(1), 7-14, doi:10.1016/j.microc.2008.08.007, 2009.

Urey, H. C.: The thermodynamic properties of isotopic substances, J. Chem. Soc., 562-581, 1947.

Wagenbach, D., Legrand, M., Fischer, H., Pichlmayer, F., and Wolff, E. W.: Atmospheric near-surface nitrate at coastal Antarctic sites, J. Geophys. Res., 103, 11007-11020, 1998.

Wang, S. Z., Bianco, R., and Hynes, J. T.: Depth-dependent dissociation of nitric acid at an aqueous surface: Car-Parrinello molecular dynamics, J. Phys. Chem. A, 113, 1295-1307, doi:10.1021/jp808533y, 2009.

Wolff, E. W. and Delmas, R. J.: Nitrate in Polar Ice, in: Ice Core Studies of Global Biogeochemical Cycles, edited by: Delmas, R. J., Springer Verlag, NATO ASI Series I, 30, 195-224, 1995.

Wolff, E. W., Jones, A. E., Martin, T. J., and Grenfell, T. C.: Modelling photochemical $\mathrm{NO}_{\mathrm{x}}$ production and nitrate loss in the upper snowpack of Antarctica, Geophys. Res. Lett., 29(20), 1944, doi:10.1029/2002GL015823, 2002.

Wolff, E. W., Jones, A. E., Bauguitte, S. J.-B., and Salmon, R. A.: The interpretation of spikes and trends in concentration of nitrate in polar ice cores, based on evidence from snow and atmospheric measurements, Atmos. Chem. Phys., 8, 5627-5634, 2008, http://www.atmos-chem-phys.net/8/5627/2008/.

Yung, Y. L. and Miller, C. E.: Isotopic fractionation of stratospheric nitrous oxide, Science, 278, 1778-1780, 1997. 